\title{
Chromatographic Methods for Coffee Analysis: A Review
}

\author{
Alexander Yashin ${ }^{1}$, Yakov Yashin ${ }^{1}$, Xiaoyan Xia ${ }^{2} \&$ Boris Nemzer ${ }^{2,3}$ \\ ${ }^{1}$ International Analytical Centre of Zelinsky Institute of Organic Chemistry of Russian, Academy of Science, \\ Moscow, Russia \\ ${ }^{2}$ Department of Research \& Development, VDF FutureCeuticals, Inc., Momence, IL, USA \\ ${ }^{3}$ Department of Food Science and Human Nutrition, University of Illinois at Urbana-Champaign, Urbana, IL, \\ USA
}

Correspondence: Boris Nemzer, FutureCeuticals, Inc., 2692 N. State Rt. 1-17, Momence, IL, USA. Tel: 812-507-1427. E-mail: bnemzer@futureceuticals.com

$\begin{array}{lc}\text { Received: April 27, } 2017 & \text { Accepted: June 2, } 2017 \quad \text { Online Published: June 17, } 2017 \\ \text { doi:10.5539/jfr.v6n4p60 } & \text { URL: https://doi.org/10.5539/jfr.v6n4p60 }\end{array}$

\begin{abstract}
Coffee has been one of the most commercialized food products and most widely researched beverage in the world for decades. It is considered a functional food, primarily due to its high content of compounds that exert antioxidant and other beneficial biological properties. This review summarized the data from analysis of coffee components, both volatile constituents and non-volatile high-molecular weight compounds performed by various chromatographic methods. A list of compounds identified by gas chromatography with mass spectrometry which define the aroma of coffee is provided. Publications on the measurement of methylxanthines (caffeine, theobromine, and theophylline), chlorogenic acids, diterpenes, sugars, amino acids, gamma-aminobutyric acid, dibasic acids, anions, and other compounds by HPLC and UHPLC-MS are reviewed. An overview of publications on the determination of organic contamination in coffee (PAHs, acrylamides, mycotoxins, etc.) and ways to reduce contamination through production technology and brewing methods are presented. Finally, an overview of the literature on authentication assessment for different grades of coffee grown in different regions is provided.
\end{abstract}

Keywords: coffee, chemical composition, chlorogenic acid, caffeine, GC, HPLC

\section{Introduction}

Coffee has been studied for many years and the research varied depending on the needs: pests, nutrition, pruning, harvesting, processing and quality. Recent studies have shown that the moderate intake of coffee reduces body fat and decreases oxidative damage-related diseases, such as type 2-diabets, cardiovascular, Alzheimer's and Parkinson's disease (Bakuradze et al., 2011; Freedman et al., 2012, O'Keefe et al., 2013). Erdem et al. (2016) indicated that cinnamic acid derivatives have been related with different biological effects including anti-inflammatory, antioxidant, anticarcinogenic, or neuroprotective activities. Coffee has a complex chemical composition and the compounds which include volatile and non-volatile compounds, diterpenes, sugar, amino acids and organic pollutants are important for coffee flavor, quality and health effects. This review article will focus on the chemical composition of coffee and their analytical techniques majorly by different chromatographic methods. We will also introduce some compounds found from different coffee processing procedures and their analytical techniques.

\section{Chromatographic Methods Used to Determine the Chemical Composition of Coffee}

Coffee contains over two thousand components-from volatile low-molecular weight to high-molecular weight compounds (Morton and Macleod, 1986). Various chromatographic methods have been used to separate and identify all kinds of mixtures, from gases and volatile compounds to high-molecular weight compounds, as well as mixtures of organic and inorganic ions (cations and anions). Therefore, almost all components of coffee can be detected by chromatographic methods. The components in a mixture are first separated on columns by different adsorption rates, and then the separated components are registered at the column outlet with detectors.

Gas chromatography has been used to separate and identify volatile and semi-volatile compounds in coffee. It is important that these compounds do not decompose during the evaporation process. Compounds with molecular 
weights up to 500-600 can be identified by gas chromatography. Liquid chromatography has been used to separate and identify non-volatile high-molecular weight compounds at temperatures close to room temperature. Therefore, even unstable compounds can be determined by liquid chromatography. For example, six quality markers in coffee, which are caffeine, trigonelline, nicotinic acid, N-methylpyridinium, 5-caffeoylquinic acid, and 5-hydroxyfurfural were simultaneously detected for three coffee matrices-green, roasted, and soluble-with the limit of quantification $0.069-0.71 \mu \mathrm{g} / \mathrm{ml}$ by HPLC-DAD. This technique is useful for routine determination of the thermal degradation rate during the roasting process (Gant, Leyva, Gonzalez \& Maruenda, 2015). Ion chromatography and ion exchange chromatography methods utilize columns filled with ion exchangers to separate ion mixtures. In thin layer chromatography, separation occurs not on columns but on plates made of glass, metal, or polymer coated with a thin layer of adsorbent material. Capillary electrophoresis techniques employ quartz capillaries with an inner diameter of $0.1 \mathrm{~mm}$, or less. Mixtures may be separated due to the electrophoretic mechanism alone (capillary zone electrophoresis), or due to electrophoretic and chromatographic mechanisms at the same time. In the latter case, a layer of adsorbent is applied on the internal walls of the capillary, or sorbent (adsorbent) is added to the mobile phase.

Gas chromatography with mass spectrometry (GC-MS) and liquid chromatography with mass spectrometry (HPLC-MS) have recently come into wide use to identify the components of the separated compounds (i.e., to conduct qualitative analysis). Table 1 provides a list of chromatography methods used to analyze coffee (based on publications).

Table 1. Chromatographic methods used for the analysis of coffee

\begin{tabular}{|c|c|c|}
\hline No. & Methods & References \\
\hline 1. & Gas chromatography (GC) & $\begin{array}{l}\text { Lercker et al, 1995; Kolling-Speer et al., 1999; Holscher and } \\
\text { Steinhart, 1992; Sanz et al., 2001; Bicchi et al., 1997. }\end{array}$ \\
\hline 2. & $\begin{array}{l}\text { Gas chromatography with } \\
\text { mass spectrometry }\end{array}$ & Dirinck et al., 2001; Costa-Freitas et al., 2001. \\
\hline 3. & $\begin{array}{l}\text { Two-dimensional } \\
\text { gas chromatography }\end{array}$ & Ryan et al., 2004 \\
\hline 4. & $\begin{array}{l}\text { Gas chromatography in coupled } \\
\text { with head-space analysis }\end{array}$ & $\begin{array}{l}\text { Semmeirich and Grosh, 1995; Maetzu et al., 2001; Procida et al., } \\
\text { 1997; Bücking and Steinhart, 2002; Rocha et al., } 2004 .\end{array}$ \\
\hline 5. & Pyrolysis gas chromatography & Harada et al., 1987 \\
\hline 6. & $\begin{array}{l}\text { High performance } \\
\text { liquid chromatography (HPLC) }\end{array}$ & $\begin{array}{l}\text { de Andrade et al., 1995; Casal et al., 2002; Bispo et al., 2002; Meger } \\
\text { et al., 1996; Dias et al., } 2010 .\end{array}$ \\
\hline 7. & HPLC-mass spectrometry & Kurzrock and Speer, 2001; Ventura et al., 2003. \\
\hline 8. & HPLC-MS/MS & Trugo, 1984 \\
\hline 9. & Gel-filtration chromatography & Daglia et al., 2004. \\
\hline 10. & Micellar chromatography & Perez-Martinez et al., 1995 \\
\hline 11. & ooranhy & o and Abrigo, 1992 \\
\hline 12. & Thin layer chromatography & Levi, 1975 \\
\hline
\end{tabular}

In addition to individual chromatographic methods, coffee has been analyzed by various combinations of chromatography methods, such as HPLC and GC, capillary electrophoresis, spectrophotometric methods, and 'electronic nose' and 'electronic tongue' systems. Table 2 provides a list of compounds which were identified in coffee (except the volatile compounds). Various estimates suggest that coffee contains 2000-3000 compounds. Table 2 shows only useful components that determine nutritional value of coffee: sugars, amino acids, fatty acids, vitamins, antioxidants, trace elements etc. 
Table 2. List of compounds identified in coffee and typical analytical methods

\begin{tabular}{|c|c|c|c|c|c|}
\hline No. & Compounds & $\begin{array}{c}\text { Typical } \\
\text { concentration }\end{array}$ & Comment & $\begin{array}{c}\text { Analytical } \\
\text { methods }\end{array}$ & References \\
\hline 1 & Chlorogenic acids & $0.6-26.4 \%$ & More than 10 types of acids & HPLC, LC/MS & $\begin{array}{l}\text { Trugo et al., 1984; Clifford, 2000; } \\
\text { Mullen et al., 2011 }\end{array}$ \\
\hline 2 & $\begin{array}{l}\text { Caffeine, } \\
\text { theobromine, } \\
\text { theophylline }\end{array}$ & $3-350 \mu \mathrm{g} / \mathrm{mL}$ & & HPLC, LC/MS & $\begin{array}{l}\text { Wanyika et al., 2010; Bispo et al., } \\
\text { 2002; Eanyika et al, } 2010\end{array}$ \\
\hline 3 & Trigonelline & $3-10 \mathrm{mg} / \mathrm{g}$ & & HPLC, LC/MS & Ky et al., 2001; Casal et al., 2000 \\
\hline 4 & Carbohydrates & $3.41-9.43 \%$ & $\begin{array}{l}\text { Saccharose, glucose, fructose, } \\
\text { arabinose, galactose }\end{array}$ & IC & Knopp et al., 2006 \\
\hline 5 & Amino acids & $\begin{array}{l}\text { 4.4-1075 } \mathrm{mg} \\
\text { per } 100 \mathrm{~g} \text { coffee } \\
\text { powder }\end{array}$ & 16 amino acids & IC, HPLC, LC/MS & $\begin{array}{l}\text { Nakhmedov et al., 1984; Bytof et } \\
\text { al., } 2005\end{array}$ \\
\hline 6 & Vitamins & less than $3 \mathrm{mg}$ & $\begin{array}{l}\text { Vitamin } B_{1} \text {, riboflavin }\left(B_{2}\right) \text {, } \\
\text { nicotinic acid }(P P) \text {, pyridoxine } \\
\left(B_{6}\right) \text {, tocopherol }(E) \text {, vitamin } B_{12}\end{array}$ & HPLC & Clarke, 1985; O'Driscoll, 2014 \\
\hline 7 & $\begin{array}{l}\gamma \text {-aminobutyric } \\
\text { acid }\end{array}$ & $30-1860 \mathrm{mg} / \mathrm{kg}$ & & HPLC & $\begin{array}{l}\text { Bytof et al., 2005, Kramer et al., } \\
2010\end{array}$ \\
\hline 8 & Serotonin & $\begin{array}{l}\text { about } 10 \mathrm{mg} / \mathrm{g} \\
\text { dry weight }\end{array}$ & 'happiness hormone' & HPLC & Kele and Ohmacht, 1996 \\
\hline 9 & Organic acids & about $1 \%$ & $\begin{array}{l}\text { Citric, malic, oxalic, acetic } \\
\text { acids, etc. }\end{array}$ & HPLC & $\begin{array}{l}\text { Kele and Ohmacht, 1996; Mabrok } \\
\text { and Deatheroge, } 1956\end{array}$ \\
\hline 10 & Anions & $\begin{array}{l}\text { phosphates } \\
0.2 \%, \text { sulfates } \\
0.1 \%\end{array}$ & $\begin{array}{l}\text { Fluoride, chloride, nitrate, } \\
\text { sulfate, phosphate }\end{array}$ & IC & Mabrok and Deatheroge, 1956 \\
\hline 11 & $\begin{array}{l}\text { Oxyaromatic } \\
\text { acids }\end{array}$ & $3-6 \%$ & $\begin{array}{l}\text { Ferulic, } \quad \mathrm{n} \text {-coumaric, } \\
\text { 3,4-dimethoxycinnamic, } \\
\text { 3,4,5-trimethoxycinnamic, } \\
\text { sinapic acids }\end{array}$ & HPLC & $\begin{array}{l}\text { Clarke, 1985; Clifford, 2000; } \\
\text { Murata et al., } 1995\end{array}$ \\
\hline 12 & Tannins & $3.6-7.7 \%$ & & Spectrophotometry & Clarke, 1985; Savolainen, 1992 \\
\hline 13 & Polysaccharides & over $12 \%$ & $\begin{array}{l}\text { Cellulose, pectic substances, } \\
\text { fibers }\end{array}$ & IC, HPLC & Clarke, 1985; Moreira et al., 2012 \\
\hline 14 & Melanoidins & $5-60 \mathrm{~g} / 100 \mathrm{~g}$ & $\begin{array}{l}\text { Dark brown natural coloring } \\
\text { agent }\end{array}$ & $\begin{array}{l}\text { HPLC, } \\
\text { assay }\end{array}$ & $\begin{array}{l}\text { Clarke, 1985; Moreira et al., 2012; } \\
\text { Pérez-Hernández et al., } 2012\end{array}$ \\
\hline 15 & $\begin{array}{l}\text { Mineral } \\
\text { substances }\end{array}$ & $3-4.5 \%$ & $\begin{array}{l}\text { Potassium, magnesium, calcium, } \\
\text { sodium, iron, manganese, zinc, } \\
\text { copper }\end{array}$ & ICP/MS & $\begin{array}{l}\text { Clarke, 1985; Abdulmadjid et al., } \\
2017\end{array}$ \\
\hline
\end{tabular}

\section{Structural Formulas and Primary Compounds in Coffee}

The structures of primary compounds in coffee are presented below (Fig. 1): caffeine, theobromine, theophylline; Trigonelline; caffeic, ferulic, protocatechuic acids; chlorogenic acids; gamma-isobutyric acid and diterpenes.<smiles>Cn1c(=O)c2[nH]cnc2n(C)c1=O</smiles>

Theobromine<smiles>O=C(O)c1ccc(O)c(O)c1</smiles>

Theophylline<smiles>Cn1c(=O)c2c(ncn2C)n(C)c1=O</smiles>

Caffeine<smiles>C[n+]1cccc(C(=O)[O-])c1</smiles>

Trigonelline

Protocatechuic acid<smiles>O=C(O)/C=C\c1ccc(O)c(O)c1</smiles><smiles>COc1cc(C=CC(=O)O)ccc1O</smiles>

Caffeic acid

Ferulic acid 


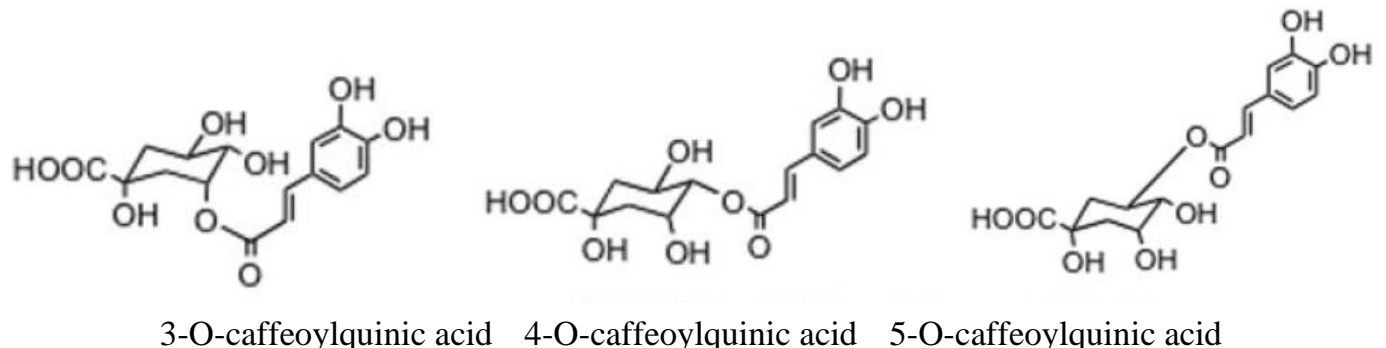

3-O-caffeoylquinic acid 4-O-caffeoylquinic acid 5-O-caffeoylquinic acid<smiles>COc1cc(/C=C/C(=O)OC(O)C(O)CC(=O)O)ccc1O</smiles>

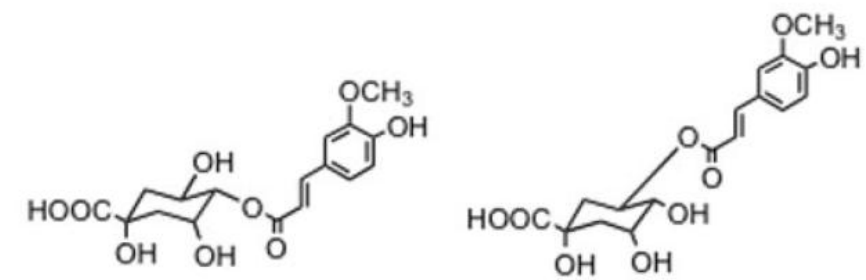

3-O-feruloylquinic acid 4-O-feruloylquinic acid 5-O-feruloylquinic acid

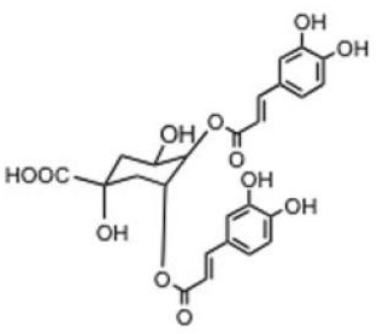

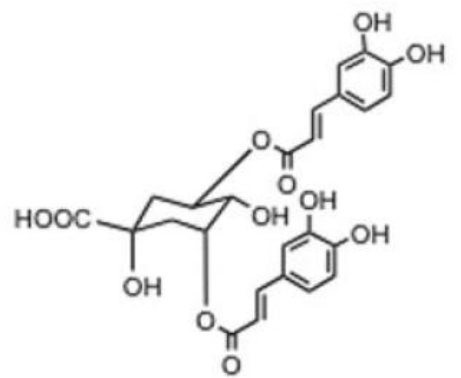

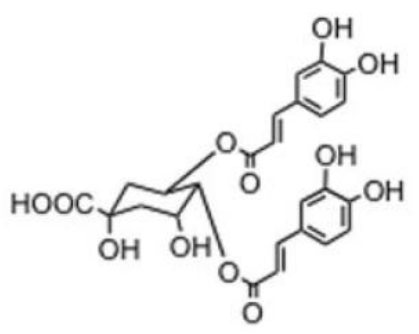

3,4-O-dicaffeoylquinic 3,5-O-dicaffeoylquinic 4,5-O-dicaffeoylquinic<smiles>O=C(/C=C/c1ccc(O)c(O)c1)OC1CC2(O)CC(=O)C(O)C1O2</smiles><smiles>O=C(/C=C/c1ccc(O)c(O)c1)OC1C2COC(=O)C(O)CC1O2</smiles><smiles>CC(C)C(=O)O</smiles>

3-O-caffeoyl-1,5-quinate

4-0-caffeoyl-1,5-quinate

Gamma-isobutyric acid<smiles>C[C@]12C=Cc3occc3[C@H]1CC[C@@]1(CC[C@H](CO)[C@@H](O)C1)C2</smiles>

Kahweol<smiles>CC12CCc3occc3C1CC[C@@]13C[C@H](O)[C@H](CO)CC1C23</smiles>

Cafestol

Figure 1. The structures of primary compounds in coffee

As one of the major primary compounds, chlorogenic acid was first isolated from coffee beans in 1908, and their structure was determined in 1932. Chlorogenic acids are mono- or diesters of quinic and cinnamic acids. Coffee contains more than fifteen chlorogenic acids along with their derivatives (lactones). Recent research indicated that the chlorogenic acid profiles of whole coffee fruits were influenced by the extraction procedures (Mullen et al., 2011; Craig et al., 2016) 
Coffee is one of the richest sources of chlorogenic and other oxyaromatic acids. Due to its health effects, chlorogenic acid consumption rate can be up to $1 \mathrm{~g}$ per day (Murata, Okada \& Homma, 1995). Eleven chlorogenic acids have been detected by three-dimensional HPLC. Farah et al. (2008) studied chlorogenic acids in extracts of green and decaffeinated coffee and identified 9 major and 17 minor components. Shan et al. (2016) simultaneous determined different chlorogenic acids in green coffee bean extracts with effective relative response factors. Köseoglu Yilmaz \& Kolak (2017) used a new solid phase extraction method (hydrophilic-lipophilic balance cartridges) combined with HPLC analysis to perform chlorogenic acid analysis recently. According to some publications, coffee is a major nutritional source of oxyaromatic acids for its consumers (Clifford, 2000; Murata, Okada, \& Homma 1995). Besides chlorogenic acid isomers (main isomer is 5-caffeoylquinic acid) and their diesters, some other hydroxycinnamic acid conjugates were also identified (Clifford, 2000) in coffee. The recognized chlorogenic acids and their derivatives, as well as their content in coffee are provided in Tables 3, 4 and 5.

Table 3. List of main chlorogenic acids (Clifford, 2000)

\begin{tabular}{lll}
\hline No. & Proper Chemical Names of Acids & Simplified Chemical Names of Acids \\
\hline 1. & Caffeoyl-3-quinic & Chlorogenic \\
2. & 4,5 -dicaffeoylquinic & Isochlorogenic A \\
3. & 3,4 -dicaffeoylquinic & Isochlorogenic B \\
4. & 3,5-dicaffeoylquinic & Isochlorogenic C \\
5. & Caffeoyl-5-quinic & Neochlorogenic \\
\hline
\end{tabular}

Table 4. List of main chlorogenic acids and their derivatives contained in coffee (Clifford, 2000)

\begin{tabular}{clc}
\hline No. & Acid Name & Typical value, $\%$ \\
\hline 1 & 5-0-caffeoylquinic & 26.4 \\
2 & 4-0-caffeoylquinic & 17.3 \\
3 & 3-0-caffeoylquinic & 16.0 \\
4 & 5-0-feruloylquinic & 14.9 \\
5 & 4-0-feruloylquinic & 4.9 \\
6 & 3-0-feruloylquinic & 4.4 \\
7 & 5-0-n-coumaroylquinic & 0.7 \\
8 & 4-0-n-coumaroylquinic & 0.9 \\
9 & 3,4-0-dicaffeoylquinic & 1.3 \\
10 & 3,5-0-dicaffeoylquinic & 0.6 \\
11 & 3-0-caffeoylquinic acid lactone & 7.5 \\
12 & 4-0-caffeoylquinic acid lactone & 5.1 \\
\hline
\end{tabular}

Table 5. Content of the main chlorogenic acids in extracts of green and decaffeinated coffee (Farah et al., 2008)

\begin{tabular}{llc}
\hline No. & Chlorogenic Acids and Their Derivatives & $\mu \mathrm{mol}$ per $0.4 \mathrm{~g}$ \\
\hline 1 & 5-caffeoylquinic & $119.8 \pm 0.23$ \\
\hline 2 & 3-caffeoylquinic & $103.3 \pm 0.14$ \\
\hline 3 & 4-caffeoylquinic & $97.4 \pm 1.2$ \\
\hline 4 & 3,4-dicaffeoylquinic & $16.8 \pm 0.01$ \\
\hline 5 & 4,5-dicaffeoylquinic & $16.2 \pm 0.32$ \\
\hline 6 & 3,5-dicaffeoylquinic & $10.2 \pm 0.06$ \\
\hline 7 & 5-feruloylquinic & $22 \pm 0.02$ \\
\hline 8 & 3-feruloylquinic & $20.7 \pm 0.69$ \\
\hline 9 & 4-feruloylquinic & $16.4 \pm 0.30$ \\
\hline 10 & 5-n-coumaroylquinic & $1.7 \pm 0.01$ \\
\hline 11 & 3-n-coumaroylquinic & $1.1 \pm 0.28$ \\
\hline 12 & diferuloylquinic (1 isomer) & $1.3 \pm 0.01$ \\
\hline 13 & caffeoylferuloylquinic acid (6 isomers) & $11.8 \pm 1.33$ \\
\hline 14 & caffeoyltryptophan & $10.5 \pm 0.15$ \\
\hline 15 & 4-caffeoylquinate & $0.3 \pm 0.01$ \\
\hline 16 & 3- feruloylquinate & $0.3 \pm 0.01$ \\
\hline 17 & 4- feruloylquinate & $0.1 \pm 0.03$ \\
\hline 18 & 3,4-dicaffeoylquinate & $0.03 \pm 0.004$ \\
\hline
\end{tabular}




\section{Composition of Volatile Components in Coffee}

In the early twentieth century little was known about coffee aromatic components. Later, different compounds such as methylamine, ammonia, trimethylamine, pyrrole, pyridine, acetone, formic and valeric acids, furfural, furfuryl alcohol were identified by classic chemical methods.

In the 1920s, 29 more compounds were detected with the financial support of the Government of Switzerland (Morton and McLeod, 1986).The most typical compounds were furfuryl mercaptan, $\alpha$-diketones and alkylpyrazines.

Twenty-seven extra compounds were identified between 1929 and 1962. From 1963 to 1982, more than 600 components were identified by gas capillary chromatography. Different classes of compounds (Table 6) which determine aroma of roasted coffee were identified by Morton \& MacLeod (1986). Primary compounds which determine coffee aroma have been study by Ky et al. (2001) (Table 7).

Table 6. Identified classes of compounds which determine aroma of roasted coffee (Morton \& MacLeod, 1986)

\begin{tabular}{llc}
\hline No. & Classes of Compounds & Number of identified compounds \\
\hline 1. & Furans & 99 \\
2. & Pyrazines & 79 \\
3. & Ketones & 70 \\
4. & Pyrroles & 67 \\
5. & Hydrocarbons & 50 \\
6. & Phenols & 42 \\
7. & Esters & 29 \\
8. & Aldehydes & 28 \\
9. & Thiazoles & 28 \\
10. & Oxazoles & 27 \\
11. & Amines and nitrogen-containing compounds & 24 \\
12. & Thiophenes & 26 \\
13. & Acids & 20 \\
14. & Alcohols & 20 \\
15. & Sulfides and sulfur-containing compounds & 16 \\
16. & Pyridines & 13 \\
17. & Lactones & 8 \\
18. & Other compounds & 9 \\
& Total: & 655 \\
\hline
\end{tabular}


Table 7. Primary compounds which determine coffee aroma (Ky et al., 2001)

\begin{tabular}{|c|c|c|c|}
\hline No. & Compounds & No. & Compounds \\
\hline 1. & $\beta$-myrcene & 31. & 2-thiophenecarbaldehyde \\
\hline 2. & limonene & 32. & 3-methyl-2-thiophenecarbaldehyde \\
\hline 3. & n-cumene & 33. & 5-methyl-2-thiophenecarbaldehyde \\
\hline 4. & naphthalene & 34. & 2-acetylthiophene \\
\hline 5. & 1-methylnaphthalene & 35. & 2-propionylthiophene \\
\hline 6. & 2-methylnaphthalene & 36. & 2-acetyl-3-methylthiophene \\
\hline 7. & 2-ethylnaphthalene & 37. & 2-acetyl-5-methylthiophene \\
\hline 8. & biphenyl & 38. & 1-(2-thienyl)-1,2-propanedione \\
\hline 9. & 3-methylbiphenyl & 39. & phenyl formate \\
\hline 10. & methylol & 40. & methyl 2-thiophenecarboxylate \\
\hline 11. & $\alpha$-terpineol & 41. & 4,5-dihydro-2(3H)thiophenone \\
\hline 12. & 2-methylbenzaldehyde & 42. & 4,5-dihydro-2(2H)thiophenone \\
\hline 13. & 2-heptanone & 43. & 2-methyl-4,5-dihydro-3(2H)-thiophenone \\
\hline 14. & 2-undecanone & 44. & 2,4-dimethyloxazole \\
\hline 15. & 3-methyl-2-hydroxy-2-cyclo-pentane-1-one & 45. & 4,5-dimethyloxazole \\
\hline 16. & geranylacetone & 46. & 2,4,5-trimethyloxazole \\
\hline 17. & $\beta$-damascenone & 47. & 2-ethyl-4,5-dimethyloxazole \\
\hline 18. & catechol & 48. & 2-methylbenzoxazole \\
\hline 19. & hydroquinone & 49. & 2-phenyloxazole \\
\hline 20. & guaiacol & 50. & 5-acetyl-2- methyloxazole \\
\hline 21. & n-methylguaiacol & 51. & 5-acetyl-2,4-dimethyloxazole \\
\hline 22. & n-ethylguaiacol & 52. & methanethyl \\
\hline 23. & n-vinylguaiacol & 53. & dimethylsulfide \\
\hline 24. & eugenol & 54. & dimethyl disulfide \\
\hline 25. & isoeugenol & 55. & dimethyl trisulfide \\
\hline 26. & thiophene & 56. & 3,3-dimethyl-1,2-dithiolane \\
\hline 27. & 3-methylthiophene & 57. & 3,3-dimethyl-1,2-dithiolane-4-one \\
\hline 28. & 4-ethyl-2-methylthiophene & 58. & 2-methyl-3-oxa-8-thiabicyclo[3,3,0]-1,4-octadiene \\
\hline 29. & benzothiophene & 59. & 2,4-dimethyl-3-oxa-8-thiabicyclo[3,3,0]-1,4-octadiene \\
\hline
\end{tabular}

In one study (Maeztu et al., 2001), aroma of espresso coffee from different botanical varieties and types of roast were investigated. Aroma components were determined by gas chromatography with mass spectrometry, volatile components were extracted by static headspace. Seventy-seven compounds were identified in all samples (Table 8). Among them, 13 key odorants have the greatest effect on coffee aroma (Maeztu et al., 2001) (Table 9). Chromatographic analyses were comparable with the sensory flavor profile. Aldehydes were found to correlate with a fruity aroma, diones with buttery aroma, and pyrazines with earthy burnt aroma.

Similar studies were conducted on samples of coffee Arabica (Colombia) and coffee Robusta (Indonesia) (Bücking \& Steinhart, 2002). Analyses were performed by gas chromatography, flame ionization detection (FID), mass spectrometry, olfactometry, and specialized headspace.

These investigations showed that approximately 30 volatile compounds (Table 10) were substantially responsible for the coffee aroma. Most typical volatile compounds are provided in the literature (Vitenberg \& Ioffe, 1984). The study also investigated how milk added to coffee influenced coffee aroma. The aroma intensity decreased due to milk lipids, proteins, and carbohydrates, however, aroma profile remained the same.

In recent years, a combination of GC-GC-FID with solid-phase microextraction was used for analysis of volatile compounds. In one study (Ryan et al., 2004), 44 volatile compounds were identified by two-dimensional chromatography (the first column with a polar phase and the second with a non-polar phase). Coffee was also analyzed by a time-of-flight mass spectrometer in this study. The coffee aroma was found to contain various classes of chemical compounds (ketones, tyrosines, furans, phenols, pyrroles, etc.). Bressanello et al. (2017) correlated the chemical composition of the coffee volatile fraction to its sensory properties. The chemical information concerning coffee aroma and flavor obtained with HS-SPEM of the ground coffee and in-solution 
Table 8. Volatile compounds identified in aroma of coffee espresso (Maeztu et al., 2001)

\begin{tabular}{|c|c|c|c|}
\hline No. & Compound name & No. & Compound name \\
\hline & Alkenes & & Ketones \\
\hline \multirow[t]{2}{*}{1.} & 1,3-pentadiene & 31. & 2-propanone \\
\hline & $\underline{\text { Sulfur compounds }}$ & 32. & 2-butanone \\
\hline 2. & Methanethiol & 33. & 2,3-butanedione \\
\hline 3. & Dimethylsulfide & 34. & 3-hexanone \\
\hline \multirow[t]{2}{*}{4.} & Dimethyl disulfide & 35. & 2,3-pentanedione \\
\hline & $\underline{\text { Aldehydes }}$ & 36. & 3,4-hexanedione \\
\hline 5. & Acetaldehyde & & Alcohols \\
\hline 6. & Propanal & 37. & 2-methyl-1-propanol \\
\hline 7. & 2-methylpropanal & 38. & 2-methylbutan-1-ol \\
\hline 8. & Butanal & 39. & 3-methyl-3-buten-1-ol \\
\hline 9. & 3-methylbutanal & 40. & 3-methyl-2-buten-1-ol \\
\hline 10. & 2-methylbutanal & 41. & 2-ethyl-1-hexanol \\
\hline \multirow[t]{2}{*}{11.} & Hexanal & & Thiophenes \\
\hline & 2-methyl-2-butanal & 42. & Thiophene \\
\hline 12. & $\frac{\text { Esters }}{\text { Formic acid methyl ester }}$ & 43. & $\begin{array}{l}\text { 2-methylthiophene } \\
\text { Pyrroles }\end{array}$ \\
\hline \multirow[t]{2}{*}{13.} & Acidic acid methyl ester & 44. & 1-methylpyrrole \\
\hline & Acidic acid ethyl ester & 45. & 1-ethyl-1H-pyrrole \\
\hline 14. & $\begin{array}{l}\text { Propionic acid methyl ester } \\
\text { 1-hydroxy-2-propanone acetate }\end{array}$ & 46. & $\begin{array}{l}\text { 2,5-dimethylpyrrole } \\
\underline{\text { Pyridines }}\end{array}$ \\
\hline \multirow{2}{*}{15.} & Furans & 47. & Pyridine \\
\hline & Furan & 48. & 2-methylpyridine \\
\hline \multirow[t]{2}{*}{16.} & 3-methylfuran & 49. & 3- ethylpyridine \\
\hline & 2-methylfuran & & Pyrazines \\
\hline 17. & 2,5-dimethylfuran & 50. & Pyrazine \\
\hline 18. & 2-vinylfuran & 51. & 2-methylpyrazine \\
\hline 19. & 2-vinyl-5-methylfuran & 52. & 2,5-dimethylpyrazine \\
\hline 20. & 2-methoxymethylfuran & 53. & 2,6-dimethylpyrazine \\
\hline 21. & 2-methyltetrahydrofurol-3-one & 54. & Ethylpyrazine \\
\hline 22. & 2-furancarboxaldehyde & 55. & 2,3-dimethylpyrazine \\
\hline 23. & 2-furfurylmethylsulfide & 56. & N-propylpyrazine \\
\hline 24. & furfuryl formate & 57. & 2-vinylpyrazine \\
\hline 25. & 2-acetylfuran & 58. & 2-methyl-6-vinylpyrazine \\
\hline 26. & 2- furfurylfuran & & Thiazoles \\
\hline 27. & Furfuryl alcohol & 59. & 1,3-thiazole \\
\hline 28. & Furfuryl acetate & 60. & 4-methylthiazole \\
\hline 29. & 5-methylfurfural & & Acids \\
\hline \multirow[t]{4}{*}{30.} & 2-furfurylfuran & 61. & Acetic acid \\
\hline & & & Lactones \\
\hline & & 62. & $\gamma$-butyrolactone \\
\hline & & 63. & $\begin{array}{l}\text { Phenolic compounds } \\
\text { 2-methoxyphenol (guaiacol }\end{array}$ \\
\hline
\end{tabular}


Table 9. Relative ratio of key odorants in coffee espresso (Maeztu et al., 2001)

\begin{tabular}{lcc}
\hline \multirow{2}{*}{ Compound name } & \multicolumn{2}{c}{$\%$ (relative) } \\
\cline { 2 - 3 } Sulfur compounds & Arabica & Robusta \\
\hline Methanethiol & $0.13 \pm 0.01$ & $0.08 \pm 0.01$ \\
Aldehydes & $0.36 \pm 0.02$ & $0.35 \pm 0.04$ \\
Acetaldehyde & $0.32 \pm 0.07$ & $0.50 \pm 0.07$ \\
Propanal & $1.80 \pm 0.25$ & $2.55 \pm 0.35$ \\
2-methylpropanal & $1.25 \pm 0.11$ & $2.33 \pm 0.34$ \\
3-methylpropanal & $2.61 \pm 0.29$ & $3.33 \pm 0.56$ \\
3-methylbutanal & 0.05 & 0.06 \\
Hexanal & $0.42 \pm 0.04$ & $0.36 \pm 0.04$ \\
Ketones & $0.63 \pm 0.04$ & $0.42 \pm 0.03$ \\
2,3-butanedione & & \\
2,3-pentanedione & $0.10 \pm 0.02$ & $0.17 \pm 0.01$ \\
Pyrazines & $0.06 \pm 0.01$ & $0.13 \pm 0.02$ \\
2-ethyl pyrazine & $0.04 \pm 0.01$ & $0.07 \pm 0.01$ \\
2-ethyl-6-methylpyrazine & & \\
2-ethyl-3,5-dimethylpyrazine & $0.11 \pm 0.01$ & $0.09 \pm 0.01$ \\
Phenolic compounds & & \\
\hline Guaiacol &
\end{tabular}

Table 10. Identified coffee odorants (Bücking and Steinhart, 2002)

\begin{tabular}{lll}
\hline No. & Compound Name & Type of Aroma \\
\hline 1. & Methanethiol & putrefactive \\
2. & Dimethylsulfide & putrefactive \\
3. & 2-methylpropanal & aroma of cocoa \\
4. & 2,3-butanedione & buttery \\
5. & 3-methylbutanal & malt-like \\
6. & 2-methylbutanal & fruity \\
7. & 2,3-pentanedione & oily \\
8. & Hexanal & aroma of leaves \\
9. & 2,3-methylbutyric acid & sweetish \\
10. & 3- methyl-2- buten-1 thiol & putrefactive \\
11. & Methional & potato-like \\
12. & 2-furfurylthiol & aroma of roasted coffee \\
13. & 1-octen-3-one & mushroom-like \\
14. & 2,3,5-trimethylpyrazine & frying \\
15. & 3-mercapto-2-methylbutyl-formate & putrefactive \\
16. & phenylacetaldehyde & honey-like \\
17. & 2-ethyl-3,5-dimethylpyrazine & earthy/frying \\
18. & Guaiacol & phenolic/burnt \\
19. & 2-isopropyl 3-methoxypyrazine & earthy/frying \\
20. & (E)-2 nonenal & cucumber-like \\
21. & 2-isobutyl-2- methoxypyrazine & aroma of sweet pepper \\
\hline
\end{tabular}

SBSE/SPME sampling combined with GC-MS to evaluate their compatibility with the cupping evaluation for quality control purposes. Yang et al. (2016) found that different temperature profiles for roasting can affect volatile aroma compounds associated with roast coffee defects (light, scorched, dark, baked and underdeveloped) by GC-MS with headspace solid phase micro extraction.

Volatile thiols are among the compounds that have the greatest impact on the flavor of coffee. Due to their extremely low odor thresholds, they have a significant sensory impact even at very low concentration. Thiols are formed during coffee roasting and are the key odorants influencing the sensory characteristics of coffee. Gas chromatography coupled to mass spectrometry is most frequently used technique for the analysis of coffee thiols. 
On-column injection at low temperature has been applied in order to prevent thermal degradation of the thiols (Czerny, Mayer \& Grosch, 1999, Dulsat-Serra, Quintanilla-Casas \& Vichi, 2016)

\section{Determination of Non-Volatile Components in Coffee}

\subsection{Simultaneous Determination of Caffeine, Theobromine, and Theophylline}

Methylxanthines, i.e. 1,3,7-trimethylxanthine (caffeine), 3-dimethylxanthine (theobromine), and 1,3-dimethylxanthine (theophylline) in coffee were determined by reversed-phase chromatography HPLC with UV detector at $273 \mathrm{~nm}$ and a Bondesil $\mathrm{C}_{18}$ column $(15 \times 0.4 \mathrm{~cm}$, particle size $5 \mu \mathrm{m})$ (Bispo et al., 2002). A mixture of methanol-water-acetic acid or ethanol-water-acetic acid in a ratio of 20:75:5 was used as an eluent. Optimum flow rate of the eluent was $0.7 \mathrm{~mL} \mathrm{~min}{ }^{-1}$. The detection limit achieved under these conditions was $1 \cdot 10^{-11} \mathrm{~g}$. Separation time was $10 \mathrm{~min}$, the yield sequence was theobromine, theophylline, and caffeine. In the same study, the content of methylxanthines was determined in some beverages (coffee, tea, cocoa, and mate) and in human urine after consumption as well. Caffeine was determined to be within $0.1 \mathrm{pg}\left(350 \mu \mathrm{g} \mathrm{mL} \mathrm{m}^{-1}\right)$, theobromine within $0.1 \mathrm{pg}\left(32 \mu \mathrm{g} \mathrm{mL}^{-1}\right)$, and theophylline within $0.1 \mathrm{pg}\left(47 \mu \mathrm{g} \mathrm{mL}^{-1}\right)$.

Table 11 shows the values of methylxanthines contained in various drinks and urine, as determined by HPLC.

Table 11. Concentrations of methylxanthines in beverages and urine (Bispo et al., 2002)

\begin{tabular}{|c|c|c|c|c|}
\hline \multirow{2}{*}{ No. } & \multirow{2}{*}{ Analyzed medium } & \multicolumn{3}{|c|}{ Concentration, $\mu \mathrm{g} \mathrm{mL}^{-1}$} \\
\hline & & Caffeine & Theobromine & Theophylline \\
\hline & Beverages & & & \\
\hline 1. & Roasted coffee & 350.0 & 17.0 & $<1 \cdot 10^{-7}$ \\
\hline 2. & Decaffeinated coffee & 26.0 & 13.0 & 47.0 \\
\hline 3. & Instant coffee & 122.0 & 12.0 & 15.0 \\
\hline 4. & Black Tea & 217.0 & 12.0 & $<1 \cdot 10^{-7}$ \\
\hline 5. & Cocoa & 4.0 & 17.0 & $<1 \cdot 10^{-7}$ \\
\hline 6. & Mate & 62.0 & 32.0 & 21.0 \\
\hline & Urine & & & \\
\hline 7. & Coffee & $3-71$ & $1 \cdot 10^{-7}$ & $1 \cdot 10^{-7}$ \\
\hline
\end{tabular}

The International Olympic Committee (IOC) banned the use of beverages in such amounts which results in excess of the maximum permitted urinary caffeine level of $12 \mu \mathrm{g} \mathrm{mL}^{-1}$. Caffeine at high concentrations leads to various disorders, such as increased secretion of acid gastric juice, kidney dysfunctions, nervous system disorders, arrhythmias, etc. The IOC does not restrict the use of theobromine and theophylline because these compounds have been used to treat asthma.

In one of the most recent studies (Wanyika, Gotebe, Gitu, Ngumba \& Maritim, 2010), caffeine content was determined in certain instant coffee (Africafe, Nescafe and Dormans) by HPLC with a spectrophotometric detector at a wavelength of $278 \mathrm{~nm}$ determined. The $250 \times 4.6 \mathrm{~mm}$ column with ODS sorbent was used; methanol-acetic acid-water (20:0.1:79.9) as mobile phase and flow rate was $1 \mathrm{~mL} \mathrm{~min}^{-1}$. The results are Dormans $1.64 \%$, Africafe $3.42 \%$ and Nescafe $3.12 \%$. The caffeine content was also determined by the spectrophotometric method - the results were about twice as high. Demissie et al. (2016) used UV/VIS spectrometer to determine caffeine in green coffee beans from hararghe, Ethiopia, using beer-lamberts's law and integrated absorption coefficient techniques.

Caffeine is known to be a pharmacologically active compound which stimulates the central nervous system. Caffeine does not accumulate in the body and is excreted in the urine within a few hours after consumption.

In one study (Rajkovic et al., 2004), quality of coffee was analyzed by different analytical methods, and the content of caffeine, heavy metals and aflatoxins was determined. Caffeine was additionally determined by HPLC in accordance with the recommendations of US Food and Drug Administration. The conditions used were: $150 \times 2.1 \mathrm{~mm}$ column with Symmetry Shield RP18, particle size $3 \mu \mathrm{m}$; acetonitrile-water (30:70) as eluent, flow rate $0.3 \mathrm{~cm}^{3} \mathrm{~min}^{-1}$ (Rajkovic, Vukoivc \& Moriera, 2004). 1.38\%, 1.59\%, and $1.61 \%$ of caffeine was detected in three different coffee samples. The total content of caffeine, phenolic compounds, and chlorogenic acids is shown in Table 12 (Trugo, de Maria, Moriera \& Petracco, 1995). 
Table 12. Composition of coffee samples (methanolic extracts) (Trugo et al., 1995)

\begin{tabular}{lccc}
\hline \multicolumn{1}{c}{ Coffee samples } & $\begin{array}{l}\text { Total content of phenolic } \\
\text { compounds, } \%\end{array}$ & $\begin{array}{l}\text { Content of } \\
\text { caffeine, } \%\end{array}$ & $\begin{array}{l}\text { Content of chlorogenic } \\
\text { acids, \% }\end{array}$ \\
\hline Instant coffee 1 & 15.14 & 2.36 & 23.8 \\
Instant coffee 2 & 14.50 & 2.99 & 23.0 \\
Light roasted coffee & 5.41 & 1.37 & 16.9 \\
Medium roasted coffee & 5.25 & 1.62 & 19.2 \\
Dark roasted coffee & 5.70 & 1.48 & 15.5 \\
\hline
\end{tabular}

Using ion chromatography and ion exchange chromatography, both inorganic (chloride, nitrate, sulfate, phosphate) and organic anions (acetate, formate, tartrate, oxalate, citrate) were determined in decaffeinated coffee on AS19 capillary column $(250 \times 0.4 \mathrm{~mm})$, gradient eluent $\mathrm{KOH}, 30^{\circ} \mathrm{C}$, eluent flow rate $10 \mu \mathrm{L} \mathrm{min}{ }^{-1}$, conductometric detector and IonPak ICE-AS6 column, conductometric detector separately (Mabrok \& Deatheroge, 1956).

\subsection{Determination of Diterpenes (Kahweol and Cafestol) in Coffee}

Many studies related to the effects of coffee consumption on human health are aimed at investigating its lipid composition such as coffee oil (Boekschotem, Engberink \& Katan, 2003). Coffee oil contains pentacyclic diterpene alcohols. Coffee diterpenes are primarily esterified by various fatty acids. Fourteen cafestol derivatives and twelve kahweol derivatives were detected (Kurzrock \& Speer, 2001). These compounds are partially preserved during the roasting process (Roos, Van Der Weg \& Urgert, 1997). But they are also dehydrated which results in the formation of dehydrated derivatives along with other decomposition products, such as kahweol, cafestol, isokahweol, and dihydroisokahweol. Cafestol was found in both coffee Arabica and in coffee Robusta whereas kahweol was found only in coffee Arabica (Roos, Van Der Weg \& Urgert, 1997). These diterpenes may contribute to the decomposition of toxic substances and provide a protective effect, particularly against aflatoxin B1 (Cavin, Holzhaeuser \& Scharf, 2002). Moreover, they were noted to have anticarcinogenic, antioxidant, anti-inflammatory, and hepatoprotective properties (Kim, Hwang \& Jeong, 2007; Lee, Choi \& Jeong, 2007; Lee $\&$ Jeong, 2007). These beneficial effects of coffee oil create great opportunities for its use in the food and cosmetics industries. The use of coffee oil as a sunscreen agent in cosmetics has already been patented (Grollier \& Plessis, 1998). However, the diterpenes, mainly cafestol, were also reported to have an undesired effect which tends to increase cholesterol levels (Kurzrock \& Speer, 2001; Kim Hwang \& Jeong, 2009; Urgert, Van Der Weg \& Kosmeijer-Schuil, 1995). A reliable analytical method is necessary for the determination of synthetic metabolic pathways of these diterpenes. In addition, the determination of diterpene content can be used for classification of coffee mixtures, in particular as a means of establishing the difference between Arabica and Robusta.

Diterpene content in coffee drinks strongly depends on the way they were prepared. Espresso coffee may contain 5-10 times as much diterpenes as in filtered coffee (Urgert, Van Der Weg \& Kosmeijer-Schuil, 1995; Ruiz del Castrillo, Herraiz \& Blanch, 1999). The Arabica beans have the highest concentration of cafestol-11 mg per $100 \mathrm{~g}$ (Kölling-Speer, Strohschneider \& Speer, 1999). In one study, diterpene content was determined in different parts of the coffee bean tissues (pericorp, perisperm, endosperm) (Dias, Campanha \& Veira, 2010). Several methods were used for analysis and identification of diterpenes, i.e., Raman spectroscopy (Rubayiza \& Meurens, 2005), GC (Urgert, Van Der Weg \& Kosmeijer-Schuil, 1995; Ruiz del Castillo, Herraiz \& Blanch, 1999; Pettitt, 1987), and HPLC (Kurzrock \& Speer, 2001; Ruiz del Castillo, Herraiz \& Blanch, 1999; Pettitt, 1987; Araujo \& Sandi, 2006). The HPLC was used most often because this method allows the direct determination of components without derivatization, avoiding the decomposition of other lipid compounds. In HPLC, the $250 \times 4.6 \mathrm{~mm}$ reversed-phase columns filled with $\mathrm{C}_{18}, 5 \mu \mathrm{m}$, were used. Acetonitrile-water mixture at a ratio of $55-45 \%$ were used as eluents. A UV detector was used for detection; the absorption maximum was set at $290 \mathrm{~nm}$ for kahweol and at $230 \mathrm{~nm}$ for cafestol. Prior to the analysis, the diterpenes were extracted from coffee beans using organic solvents, such as n-hexane, diethyl ether, petroleum ether, followed by saponification by an alcoholic KOH solution. Diterpene compounds were also determined in Arabica coffee by HPLC-DAD (Erny, Moeenfard \& Alves, 2015). In Arabica and Robusta coffee beverages, previously unknown compounds affecting their flavor were identified by high resolution HPLC-MS (Nascimento et al., 2015).

\subsection{Determination of Sugars in Coffee}

The content of low molecular weight sugars was investigated in green Arabica coffee beans which were obtained after flesh of the berries was separated from the seeds by wet or dry methods (Knopp, Bytof \& Selmar, 2006). 
Low content of fructose and glucose was noted in washed coffee beans (wet method). The content of these sugars was higher when coffee beans were dry processed. Laboratory models of these processing methods have confirmed the above results. Table 13 shows the content of monosaccharides in coffee samples of several manufactures from various countries. As can be seen from these data, saccharose typically has the highest content level.

Table 13. Concentration of the most common sugars in commercial green coffee samples (Knopp, Bytof \& Selmar, 2006)

\begin{tabular}{llccc}
\hline Type of green coffee and & Country/Province & \multicolumn{3}{c}{ Content of sugars, \% } \\
\cline { 3 - 5 } processing method & & Saccharose & Fructose & Glucose \\
\hline Arabica (dry) & Brazil 1 & 9.25 & 0.14 & 0.04 \\
& Brazil 2 & 8.70 & 0.15 & 0.04 \\
& Brazil 3 & 7.60 & 0.02 & 0.01 \\
& Ethiopia 1 & 8.26 & 0.17 & 0.04 \\
& Ethiopia 2 & 6.30 & 0.01 & 0.01 \\
& Mexico & 9.64 & 0.05 & 0.03 \\
& Honduras & 6.92 & 0.05 & 0.03 \\
\hline Arabica (wet) & Colombia 1 & 8.76 & 0.06 & 0.04 \\
& Colombia 2 & 8.07 & 0.01 & 0.01 \\
& Colombia & 7.16 & 0.20 & 0.01 \\
& El Salvador & 9.89 & 0.05 & 0.02 \\
& Peru & 8.21 & 0.05 & 0.02 \\
& Kenya & 9.31 & 0.06 & 0.03 \\
& Cameroon & 5.87 & 0.04 & 0.01 \\
\hline Robusta (dry) & Vietnam & 3.15 & 0.16 & 0.10 \\
& Ivory Coast & 3.27 & 0.18 & 0.03 \\
& Uganda & 4.55 & 0.11 & 0.03 \\
& Indonesia & 4.85 & 0.18 & 0.06 \\
\hline
\end{tabular}

Saccharose content is significantly lower in the Robusta than the Arabica. In the Arabica coffee, the saccharose content remains basically the same and does not depend either on the processing method or location where it was grown. A similar conclusion can be drawn with respect to glucose. However, the fructose content does depend both on the processing method and the location where it was grown. The fructose content in the Robusta coffee is higher compared with the Arabica, yet the glucose content is approximately the same in both grades. Typical content of sugars is provided in Table 14. Coffee processing technology can be ascertained by the content of fructose and glucose.

Table 14. The content of different sugars in the Arabica coffee beans (Brazil, Province Acaia) obtained by the dry processing method (Knopp, Bytof \& Selmar, 2006)

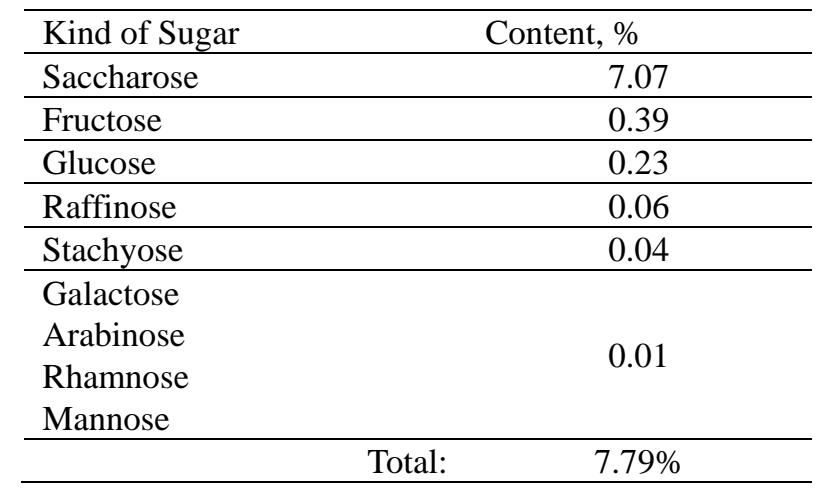

The content of sugars was determined by ion exchange chromatography on the Dionex PA20 column with amperometric detector at gold electrodes; $\mathrm{NaOH}$ solution as eluent and the flow rate was $0.5 \mathrm{~mL} \mathrm{~min}^{-1}$.

\subsection{Determination of Amino Acids in Coffee}

Amino acids in coffee have been determined by a classic ion exchange chromatography in the form of 
derivatives as well as by a direct method with amperometric detection (Nakhmedov, 1984). Amino acids were also separated by HPLC and ion-pair chromatography in the form of derivatives with ortho-phthalic dialdehyde by other researchers (Bytof et al., 2005). The following amino acids were identified in green coffee: glutamic acid, aspartic acid, serine, histidine, glycine, arginine, alanine, tyrosine, methionine, valine, norvaline, tryptophan, phenylalanine, isoleucine, leucine, lysine, etc with concentration range 4.4-1075 mg per 100g of coffee dry powder. The content of protein amino acids from different process methods are different. It is higher in dry processed coffee than wet processed coffee.

As a non-protein amino acid, Gamma-aminobutyric acid ( $\gamma$-aminobutyric acid, GABA) is an inhibitory neurotransmitter which reduces brain activity, especially during sleep, and reduces depression. The World Health Organization believes that by 2020 depression will be the second most common disease after cardiovascular diseases. $\gamma$-aminobutyric acid (GABA) is contained in the Gabaron tea grade which was specially cultivated in Japan. GABA is also contained in coffee.

Drinks containing GABA are considered to be medicinal, they have the following basic biological properties:

- Help cure stress-related insomnia and improve sleep quality;

- Reduce risk of cardiovascular diseases;

- Have anti-hypertensive properties;

- Help cure alcoholism (alcoholics have decreased GABA content in the blood);

- Help in treatment of diabetes, Alzheimer's disease and Parkinson's disease;

- Retard the aging process.

In one study, the impact of coffee technological processing on the GABA content was investigated (Bytof, Knopp $\&$ Schieberle, 2005). Significant amounts of GABA were found in green coffee obtained by dry method. Coffee beans produced by the wet method had significantly less GABA.

GABA and other amino acids were determined by high performance liquid chromatography (de Andrade, Pinheiro \& Lopes, 1995; Granvogl \& Schieberle, 2007; Casal, Oliveira \& Ferreira, 2002, Bispo et al., 2002; Meger, Ngiruwonsanga \& Henze, 1996; Dias, Campanha \& Veira, 2010). It was reported that GABA is produced in plants by $\alpha$-decarboxylation of glutamic acid.

\subsection{Determination of Heavy Metals}

As for heavy metals, in accordance with the Regulation of Health Food, coffee may contain only trace amounts. In one study, less than $0.1 \mu \mathrm{g} \mathrm{kg}^{-1}$ of lead and less than $0.05 \mu \mathrm{g} \mathrm{kg}^{-1}$ of arsenic was detected by atomic absorption spectrophotometry (Rajkovic, Vukovic \& Demin, 2004). Maximum permissible concentration of these elements is below $1 \mu \mathrm{g} \mathrm{kg}^{-1}$.

\section{Determination of Organic Pollutants in Coffee}

There are some compounds undesirable for flavor and bioactivity of the brew which occur due to inappropriate harvesting, weather conditions during processing or improper storage of coffee. Most of these compounds are microbial by products such as ochratoxin and specific biogenic amines. Acrylamide and polycyclic aromatic hydrocarbons could be formed by high roasting temperature.

\subsection{Determination of Polycyclic Aromatic Hydrocarbons (PAHs)}

The PAHs were determined in coffee by HPLC with different detection methods and GC-MS. (Shi et al., 2016; Guatemala-Morales et al., 2016; Ventura et al., 2003; Pissinatti et al., 2015). Seven types of PAHs were detected in coffee by HPLC with fluorimetric detection (Ventual et al., 2003) (benzo(a)anthracene, benzofluoranthene, benzo(a)pyrene, benzoperylene, dibenzoanthracene, indenopiren). Separation was performed on a $100 \times 4.6 \mathrm{~mm}$ column filled with Chrom Sep with gradient elution. Excitation wavelengths of the fluorimetric detector were set at 274, 296, and $300 \mathrm{~nm}$, emission wavelengths were 414, 406, and $470 \mathrm{~nm}$, respectively. The PAH detection limit was in the range of $0.2 \mathrm{ng} \mathrm{kg}^{-1}$, the linear range was between $0.2-10 \mu \mathrm{g} \mathrm{L}^{-1}$. Ten polyaromatic hydrocarbons were determined in the roasted coffee by GC-MS on 24 commercial samples at levels of $1.00-11.29 \mu \mathrm{g} \mathrm{kg}^{-1}$ (Pissinatti et al., 2015).

The concentrations of PAHs in different grades of coffee are different, with lower content in green coffee. Benzo(a)pyrene was not found in green coffee at all. The most amount of benzo(a)pyrene was determined in 
instant coffee and in roasted coffee. It was shown that the content of benzo(a)pyrene depends on the roasting degree (Kayali-Sayadi et al., 1999; Badolato, et al., 2006). Typically, benzo(a)pyrene served as an indicator of the overall contamination of coffee with PAHs.

\subsection{Determination of Acrylamide in Coffee}

Acrylamide exerts a carcinogenic effect (Tarcke, Rydberg, Karlsson \& Tomnqvist, 2002). Acrylamide is synthesized when carbohydrate-rich foods are heated (Taeymans et al., 2004). One of the possibilities is that acrylamide synthesis occurs via Maillard reaction when amino acids react with carbonyl compounds during heating. Significant amounts of acrylamide can be formed during coffee roasting process, therefore coffee may become a source of acrylamide in people's every day diet. Reliable and quick method to measure acrylamide level in coffee is needed to optimize the technology of making coffee with minimal acrylamide level. As is well-known, some compounds which are formed in the roasting process give coffee unmatched aroma and pleasant taste. At the same time, some undesirable and even harmful compounds could also be formed in the roasting process.

Measuring acrylamide level in coffee is a challenging task because it requires pre-extraction from a complex matrix. Gas chromatography, liquid chromatography, GC-MS (Surma, Sadowska-Rociek, Cieślik \& Sznajder-Katarzyńska, 2017; Ono et al., 2003; Biedermann et al., 2002) and LC-MS ( Khan et al., 2017; Becalski, Lau, Lewis \& Seaman 2003; Roach, Andrzejewski, Gay, Nortrup \& Musser, 2003; Zyzak et al., 2003) are used most often. The acrylamide contents are different in some commercial coffee from several manufactures in different countries, with 42-338 $\mathrm{ng} \mathrm{g}^{-1}$ in instant coffees and about $50 \mathrm{ng} \mathrm{g}^{-1}$ in filtered coffee.

The effect of temperature and roasting time on the acrylamide content in coffee was also studied (Senyuva \& Gökmen, 2005). The same sample was roasted at $150^{\circ} \mathrm{C}, 200^{\circ} \mathrm{C}$, and $225^{\circ} \mathrm{C}$ for $30 \mathrm{~min}$. At $150^{\circ} \mathrm{C}$, the acrylamide content was increasing during all roasting period, whereas at $200^{\circ} \mathrm{C}$ and $225^{\circ} \mathrm{C}$, the acrylamide content was increasing only during the first 10 minutes, after that, the acrylamide content was continuously decreasing during the remaining roasting time (up to $30 \mathrm{~min}$ ). The level of acrylamide cut down to 5\%.

Coffee also changed its color during roasting process. Nonlinear correlation between the color of coffee, as measured by Minolta's CM-3600d spectrophotometer, and acrylamide content in it was noted for 9 types of coffee. The highest acrylamide level, $338 \mathrm{ng} \mathrm{g}^{-1}$, was noted in Jacobs Monarch coffee.

LC-MS method used for measuring acrylamide was quite fast, reliable, and accurate (Senyuva \& Gökmen, 2005). Prior to the analysis, samples were extracted with methanol and purified.

\subsection{Determination of ochratoxin in coffee}

Ochratoxin is one of the carcinogenic mycotoxins which may develop in foods and beverages under inadequate production processes and storage conditions. In many countries, the maximum allowable levels of ochratoxin are set within 2-50 $\mathrm{ng} \mathrm{g}^{-1}$.

The EU Commission plans to establish standards for ochratoxin levels in green and roasted coffee. AOAC current method for the determination of ochratoxin in coffee was first published in 1975 (Levi, 1975). This method is based on the thin-layer chromatography with an insufficiently sensitive detection (maximum permissible concentration $20 \mathrm{ng} \mathrm{g}^{-1}$ ).

It has been planned to develop a new method for the determination of ochratoxin in coffee. In recent years, dozens of articles were published on this subject. In one study, it was suggested to use reversed-phase HPLC with fluorimetric detection. The presence of ochratoxin in coffee was confirmed by mass spectrometry. The detection limit was $0.1 \mathrm{ng} \mathrm{g}^{-1}$. Twenty samples of coffee from different countries, such as Brazil, Colombia, Zimbabwe, India, and Indonesia, were analyzed. Extraction was carried out with $1 \% \mathrm{NaHCO}_{3}$. A polymer-based column (Oasis MAX) which employs both reversed-phase and ion-exchange mechanisms of retention was used in this study. Using such a state-of-the-art technique, ochratoxin in the amounts exceeding the MPC was not detected either in green or in roasted coffee.

Another publication describes a method for measuring an ochratoxin level in green coffee by immunoaffinity column cleanup followed by HPLC separation and analysis (Vorgas, Dos Santos \& Pittet, 2005). This technique was tested in 8 countries as part of preparation for establishing it as the EU official method.

A new HPLC-MS-MS method was developed for simultaneous determination of 21 mycotoxins in coffee beverages. Mycotoxins were detected at the $\mu \mathrm{g} \mathrm{kg}^{-1}$ level. Ochratoxin - a mycotoxin regulated in coffee in Europe - was measured in two samples at the maximum allowable level (García-Moraleja, Font, Mañes \& Ferrer, 2015). 
Eight types of aflatoxins $\left(B_{1}, B_{2}, G_{1}, G_{2}, M_{1}, M_{2}, G M, G M_{2}\right)$ could be formed out of the three structural variants of aflatoxins. Determining aflatoxin $B_{1}$ is the most important goal since it is the precursor of all types of aflatoxins (Rajkovic, Vukovic \& Demin, 2004).

Aflatoxins were determined by HPLC with fluorimetric detection at the detection limit of $2.5 \mu \mathrm{g} \mathrm{kg}^{-1}$, excitation wavelength of $366 \mathrm{~nm}$ and emission wavelength $460 \mathrm{~nm}$. In all samples of Grand and Don coffee varieties (Golex Product), the total amount of $B_{1}$ and $G_{1}$ aflatoxins was less than $2.5 \mu \mathrm{g} \mathrm{kg}^{-1}$ whereas the maximum permissible concentration is $5.0 \mathrm{\mu g} \mathrm{kg}^{-1}$ (Regulation of Health Food).

The harmful substances in coffee can be eliminated or reduced to a minimum (below MPC) by adherence to the adequate technology for gathering and processing green coffee beans, and proper storage conditions of the finished product. It is worth to mention people should avoid to consume coffee or tea along with foods containing significant amount of nitrates since hydrogen cyanide may be formed (Seto et al., 2008).

\section{Identification of Coffee}

Identifying characteristics of coffee at different stages of its production are determined by: the shape and size of coffee beans, its organoleptic characteristics, element compositions (Krivan et al., 1993; Martin et al., 1998 and 1999; Weckerle et al., 2002; Serra et al., 2001; Wieser et al., 2002; Rodrigues et al., 2010), aroma analysis (Dirinck et al., 2001), physical and chemical composition (Rocha et al., 2004; Martin et al., 1998; Ky et al., 2001; Casals et al., 2000; Guerrero et al., 2001; Carrera et al., 1998; Valdenbro et al., 1999; Bertrand et al., 2005; Martin, et al., 2001; Gonzales et al., 2001; Anderson et al., 2002; Kemsley et al., 1995; Dupuy et al., 1995; Suchanek et al., 1996; Downey et al., 1996). For identification of botanical species of coffee beans, assessment of the outward anatomy and morphology may sufficient. Arabica and Robusta coffee beans differ in shape and size. Green Arabica coffee beans have an elongated shape 6-15mm long. Green Robusta coffee beans have rounded shape $4-9 \mathrm{~mm}$ long. After roasting, the bean size is increased by $25-50 \%$.

Coffee Arabica has richer aroma than coffee Robusta. Arabica coffee tastes slightly sour whereas Robusta coffee has a more bitter taste. Experts can organoleptically—by taste and aroma—distinguish natural roasted Arabica and Robusta coffee.

Modern physicochemical methods, primarily chromatography, provide the most reliable criteria for identification of coffee authenticity at all production and preparation stages because the main varieties of coffee Arabica and Robusta differ in content of sugars, caffeine, theobromine, theophylline, trigonelline, chlorogenic acids and other compounds (Table 15).

Table 15. Overall typical chemical composition of Arabica and Robusta coffee

\begin{tabular}{llll}
\hline No. & Compounds & Arabica & Robusta \\
\hline 1 & Water-soluble extractive substances & $19-20 \%$ & $24-27 \%$ \\
\hline 2 & Chlorogenic acids (more than 10) & $5.5-8 \%$ & $9-11 \%$ \\
\hline 3 & Caffeine & $0.6-1.2 \%$ & $1.8-3 \%$ \\
\hline 4 & Theophylline & $1-4 \%$ & $10-100 \mathrm{ppm}$ \\
\hline 5 & Theobromine & $1.3-2.5 \%$ & $0.1-0.67 \%$ \\
\hline 6 & Trigonelline & $1-1.2 \%$ & $0.6-0.7 \%$ \\
\hline 7 & Diterpene glycosides & $290-340 \mathrm{mg} / \mathrm{kg}$ & $10-45 \mathrm{mg} / \mathrm{kg}$ \\
\hline 8 & Carbohydrates. & & \\
& Polysaccharides, cellulose & Over 12\% & Over $12 \%$ \\
& Monosugars & $0.7-1 \%$ & $0.7-1 \%$ \\
\hline 9 & Protein substances (by amino nitrogen) & $1.55-1.63 \%$ & $1.36-1.72 \%$ \\
\hline 10 & Amino acids (free) & Over 1.6\% & Over 1.6\% \\
\hline 11 & Tannins & $3.6-7.7 \%$ & $2.2-6.6 \%$ \\
\hline 12 & Free fatty acids (linoleic, palmitic, oleic, myristic, linolenic, etc.) & $0.5-3 \%$ & $1.2-3.8 \%$ \\
\hline 13 & Organic acids (citric, malic, maleic, oxalic, acetic, etc.) & About 1\% & About $1 \%$ \\
\hline 14 & Vitamins B1, B2, B6, pantothenic acid, & Less than 3 mg & Less than 3 mg \\
& nicotinic acid (PP), tocopherol (E). & & \\
\hline 15 & Mineral substances (Na, Mg, K, Fe, Mn, Zn, etc.) & $3-4.5 \%$ & $3-4.5 \%$ \\
\hline
\end{tabular}

Note: Coffee contains polyamines and gamma-aminobutyric acid. The table shows average values-the actual values depend on coffee variety and growing area. 
Recently the elemental detection of green bean of arabica and robusta coffee from Gayo Highland, Aceh-Indonesia, has been identified by using fundamental Nd-YAG Laser for distinguishing the characteristics of both coffees. It is noticed that the order of elements concentration from highest to lowest are $\mathrm{Ca}>\mathrm{K}>\mathrm{CN}>\mathrm{Na}>\mathrm{C}$ for arabica and $\mathrm{K}>\mathrm{Ca}>\mathrm{CN}>\mathrm{Na}>\mathrm{N}$ for robusta. The ratio of intensities of these elements to $\mathrm{C}$ intensity could be used as a marker to discriminate kind of coffee for the purpose of authentication (Abdulmadjid, Meilina, Hedwig \& Kurniawan, 2017).

The state-of-the-art equipment, namely, multicollector inductively coupled plasma mass spectrometer (MC-ICP-MS) and isotope ratio mass spectrometer (IRMS), were used to determine coffee authenticity and its origin (Bertrand, Etienne, Lashermes, Guyot \& Dovrieux, 2005). Sixty samples from twenty different geographical areas were analyzed. The ${ }^{87} \mathrm{Sr}{ }^{86} \mathrm{Sr}$ isotope ratio and average value of the ${ }^{18} \mathrm{O}_{2}$ isotope were determined in the samples. The measurement results showed a high degree authenticity of coffee origin, especially for countries in South America.

Different compounds from coffee have been used to assess the grade of coffee and its origin. Samples of coffee (fruit, beans, husks) from China, India, and Mexico were analyzed with regards to the content of chlorogenic acids, caffeine, and total polyphenols (Mullen et al., 2013). Among chlorogenic acids (69 chlorogenic acids are currently identified in green coffee beans), 5-O-caffeoylquinic acid was prevalent. The analysis was performed by UHPLC coupled with a QE Orbitrap MS. The samples' antioxidant capacity was also determined. The content of chlorogenic acids in coffee from India and Mexico was similar (18.8 and $22.9 \mathrm{mg} \mathrm{g}^{-1}$ in Arabica coffee beans; 27.3 and $27.4 \mathrm{mg} \mathrm{g}^{-1}$ in Robusta coffee beans, respectively), while it was significantly lower in coffee beans from China (1.7 and $\left.7.2 \mathrm{mg} \mathrm{g}^{-1}\right)$. Also, coffee from China contained a third to a half of the amount of polyphenols in coffee from India and Mexico, although the total content of flavonoids was about the same. Antioxidant activity measured by FRAP was 2-2.5 times lower in coffee from China than in coffee from India and Mexico (112, 227 and $267 \mu \mathrm{mol} \mathrm{g}{ }^{-1}$, respectively, for Arabica coffee). Coffee husk turned out to be a rather rich source of procyanidins, flavanols, and flavonols-about 115-130, 18-30, 260+ $\mathrm{g} \mathrm{g} \mathrm{g}^{-1}$, respectively. Mehari et al., (2015) simultaneously determined the alkaloids in green coffee beans from Ethiopia using chemometric method to evaluate the geographical origin of coffee. High performance liquid chromatography was applied and the limits of detection for the method were established. Study showed that the application of linear discriminant analysis provided $75 \%$ correct classification of samples into the respective production regions, with a $74 \%$ prediction success rate. The moderate classification efficiency obtained when using alkaloid data demonstrated the potential of using this class of compounds in discriminant models for determination of the geographical origin of green coffee beans from Ethiopia.

\section{Conclusion}

Coffee is one the most popular beverage and consumed by millions of people all over the world. Numerous factors throughout the coffee production chain, from plant to cup, have been shown to have effects on the color, aroma, and flavor of coffee. This article reviews publications on qualitative and quantitative determination of volatile and non-volatile compounds in green and roasted coffee which determine its aroma, taste and quality, majorly by chromatographic methods.

Using these methods, the following antioxidants and nutrients were identified in coffee: oxyaromatic acids, chlorogenic acids, vitamins, amino acids, sugars, diterpene glycosides, trace minerals, etc. Knowing the chemical composition of coffee will facilitate the study of coffee impact on human health and disease prevention.

It has been reliably proven by now that moderate consumption of coffee reduces cardiovascular risk, prevents the development of type 2 diabetes, protects the liver and even helps combat liver cirrhosis, reduces the risk of neurodegenerative diseases such as Parkinson's and Alzheimer's diseases, and protects against asthma. In general, coffee intake decreases oxidative stress which precedes many dangerous diseases.

\section{References}

Abdulmadjid, S. N., Meilina, H., Hedwig, R., \& Kurniawan, K. H. (2017). Elemental detection of Arabica and Robusta green bean coffee using laser-induced plasma spectroscopy. AIP Conference Proceeding, 1801, 050001. https://doi.org/10.1063/1.4973099

Anderson, K. A., \& Smith, B.W. (2002). Chemical profile to differentiate geographic growing origins of coffee. J. Agric. Food Chem, 50, 2068-2075. https://doi.org/10.1021/jf011056v

Araujo, J. M. A., \& Sandi, D. (2006). Extraction of coffee diterpenes and coffee oil using supercritical carbon dioxide. Food Chem, 101, 1087-1094. 
Badolato, E. S. G., Martins, M. S., Aued-Pimentel, S., Alaburda, J., Kumagai, E. E., Baptista, G. G., \& Rosenthal, A. (2006). Sistematic Study of Benzo[a]Pyrene in Coffee Samples. J. Brazilian Chem. Soc., 117, 989-993. https://doi.org/10.1590/s0103-50532006000500025

Bakuradze, T., Boehm, N., Janzowski, C., Lang, R., Hofmann, T., Stockis, J. P., Albert, F. W., Stiebitz, H., Bytof, G., Lantz, I., Baum, M., \& Eisenbrand, G. (2011). Antioxidant-rich coffee reduces DNA damage, elevates glutathione status and contributes to weight control: results from an intervention study. Mol. Nutr. Food Res. 55(5), 793-797

Becalski, A., Lau, B. P. Y., Lewis, D., \& Seaman, S. W. (2003). Acrylamide in foods. Occurrence, sources and modeling. J. Agric and Food Chem, 51, 802-808. https://doi.org/10.1021/jf020889y

Bertrand, B., Etienne, H., Lashermes, P., Guyot, B., \& Dovrieux, F. (2005). Can near-infrared reflectance of green coffee be used to detect introgression in coffea Arabica cultivars? J. Sci. food Agric., 85, 955-962. https://doi.org/10.1002/jsfa.2049

Bicchi, C. P., Panero, O. M., Pellegrino, G. M., \& Vanni, A. C. (1997). Characterization of roasted coffee and coffee beverages by solid-phase micro-extraction/Gas Chromatography and Principal Component Analysis. J. Agric. Food Chem, 45, 4680-4686. https://doi.org/10.1021/jf9704827

Biedermann, M., Biedermann-Brem, S., Noti, A., \& Grob, K. (2002). Two GC-MS methods for the analysis of acrylamide in foodstuff. Mitteilung Lebens mittel und Hygiene, 93, 638-652.

Bispo, M. S., Veloso, M. C., Pinheiro, H. L. de Oliveira, R. F. S., Reis, J. O. N., \& de Andrade, J. B. (2002). Simultaneous determination of caffeine, theobromine and theophylline by High-Performance liquid chromatography. Chromatogr. Science, 40, 45-48. https://doi.org/10.1093/chromsci/40.1.45

Boekschotem M.V., Engberink M.F., Katan M.B., \& Schouten E.G. (2003). Reproducibility of the serum lipid response to coffee oil in healthy volunteers. Nutr. J. v. 2, p. 1-8. https://doi.org/10.1186/1475-2891-2-8

Bressanello, D., Liberto, E., Cordero, C., Rubiolo, P., Pellegrino, G., Ruosi, M. R., \& Bicchi, C. (2017). Coffee aroma: Chemometric comparison of the chemical information provided by three different samplings combined with GC-MS to describe the sensory properties in cup. Food Chemistry, 214, 218-226. https://doi.org/10.1016/j.foodchem.2016.07088

Bücking, M., \& Steinhart, H. (2002). Headspace and Sensory Analysis Characterization of the Influence of Different Milk Additives on the Flavor Release of Coffee Beverages. J. Agric. Food Chem, 50, 1529-1534. https://doi.org/10.1021/jf011117p

Bytof, G., Knopp, S.-E., Schieberle, P., Teutsch, I., \& Selmar, D. (2005). Influence of processing on the generation of $\gamma$-aminobutyric acid in green coffee beans. Eur. Food Res. Technol., 220, 245-250.

Carrera, F., Leon-Camacho, M., Pablos, F., \& Gonzalez, A. G. (1998). Authentication of green coffee varieties according to their sterolic profile. Anal. Acta., 370, 131-139. https://doi.org/10.1016/s0003-2670(98)00303-1

Casal, S., Oliveira, M. B. P. P., \& Ferreira, M. A. (2002). Determination of biogenic amines in coffee by an optimized liquid chromatographic method. J. Liquid Chromatogr. And Related Technologies, 25, 2535-2549. https://doi.org/10.1081/jlc-120014273

Casal, S., Oliveira, M. B. P. P., Alves, M. R., \& Ferreira, M. A. (2000). Discrimination analysis of roasted coffee varieties for trigonelline, nicotinic acid and caffeine content. J. Agric Food Chem., 48, 3420-3424. https://doi.org/10.1021/jf990702b

Cavin, C., Holzhaeuser, D., Scharf, G., Constable, A., Huber, W. W., \& Schilter, B. (2002). Cafestol and kahweol, two coffee specific diterpenes with anticarcinogenic activity. Food Chem. Toxicol., 40, 1155-1169. https://doi.org/10.1016/s0278-6915(02)00029-7

Clarke, R. J., \& Mocrae, R. Coffee vol. 1. Chemistry. Elsevier, New York 1985.

Clifford, M. N. (2000). Chlorogenic acids and other cinnamates-nature, occurrence, dietary burden, absorption and metabolism. J. Sci. Food Agr., 80, 1033-1043. https://doi.org/10.1002/(sici)1097-0010(20000515)80:7\%3C1033::aid-jsfa595\%3E3.3.co;2-k

Costa-Freitas, A. M., Parreira, C., \& Vilas-Boas, L. (2001). Comparison of two SPME fibers for differentiation of coffee by analysis of volatile compounds. Chromatographia, 54, 647-652.

Craig, A. P., Fields, C., Liang, N., Kitts, D. \& Erickson, A. (2016). Performance review of a fast HPLC_UV 
method for the quantification of chlorogenic acids in green coffee bean extracts. Talanta, 154, 481-485. https://doi.org/ 10.1016/j.talanta.2016.03.101

Czerny, M., Mayer, F., \& Grosch, W. (1999). Sensory study on the character impact odorants of roasted Arabica coffee. Journal of agricultural and Food Chemistry, 47, 695-699

Daglia, M., Racchi, M., Papetti, A., Lanni, C., Govoni, S., \& Gazzani, G. (2004). In vitro and ex vivo antihydroxyl Radical Activity of Green and Roasted Coffee. J. Agric. Food Chem., 52, 1700-1704. https://doi.org/10.1021/jf030298n

de Andrade, J. B., Pinheiro, H. L. C., Lopes, W. A., Martins, S., Amorin, A. M. M., \& Brandao, A. M. (1995). Determination of caffeine in beverages by HPLC. Quimica Nova., 18, 379-381.

Demissie, E. G., Woyessa, G. W., \& Abebe, A. (2016). UV/VIS spectrometer determination of caffeine in green coffee beans from hararghe, Ethiopia, using beer-lamberts's law and integrated absorption coefficient techniques. Chemistry \& Chemical Engineering, Biotechnology, Food Industry, 17(2), 109-123

Dias, R. C. E., Campanha, F. G., Vieira, L. G. E., Ferreira, L. P., Pot, D., Marraccini, P., \& Benassi, M. D, T. (2010). Evaluation of kahweol and cafestol in Coffee Tissues and roasted coffee by a new high-performance Liquid Chromatography Methodology. J. Agric. Food Chem., 58, 88-93. https://doi.org/10.1021/jf9027427

Dirinck, I., van Leuven, I., \& Dirinck, P. (2001). SDE-GC-MS analysis and titratable acidity for objective flavour characterization of coffee. Spec. Publ. - R. Soc. Chem., 269, 248-252.

Dirinck, M. I., Van Lenven, I., \& Dirinck, J. P. (2001). Analytical flavor characterization and classificztion of Arabica anf robusta coffees from different origins. Proceedings of $19^{\text {th }}$ ASIC Colloquium (Trieste) ASIC, Paris, France.

Downey, G., \& Boussion, J. (1996). Authentication of coffee bean variety by near-infrared reflectance spectroscopy of dried extract. J. Sci. Food Agric., 71, 41-49. https://doi.org/10.1002/(sici)1097-0010(199605)71:1\%3C41::aid-jsfa546\%3E3.0.co;2-i

Dulsat-Serra, N., Quintanilla-Casas, B., \& Vichi, S. (2016). Volatile thiols in coffee: A review on their formation, degradation, assessment and influence on coffee sensory quality. Food Research International, 89, 982-988. https://doi.org/ 10.1016/j.foodres.2016.02.008

Dupuy, N., Huvenne, J. P., Duponchet, L., \& Legrand, P. (1995). Classification of green coffees by FTIR analysis of dry extract. Appl. Spectrosc, 49, 580-585. https://doi.org/10.1366/0003702953964174

Erdem, S. A., Senol, F. S., Budakoglu, E., Orhan, I. E., \& Sener, B. (2016). Exploring in vitro neurobiological effects and high-pressure liquid chromatography-assisted quantitation of chlorogenic acid in 18 Turkish coffee brands. Journal of Food and Drug Analysis, 24, 112-120. https://doi.org/10.2016/j.jfda.2015.08.001

Erny, G. L., Moeenfard, M., \& Alves, A. (2015). Liquid Chromatography with Diode Array Detection Combined With Spectral Deconvolution for the Analysis of Some Diterpene Esters in Arabica Coffee Brew. J Sep Sci., 38(4), 612-620. https://doi.org/10.1002/jssc.201401095

Farah, A., Monteiro, M., Donangelo, C. M., \& Lafay, S. (2008). Chlorogenic acids from green coffee extract are highly bioavailable in humans. J. Nutr., 138, 2309-2315

Freedman, N. D., Park, Y., Abnet, C. C., Hollenbeck, A. R., \& Sinha, R. (2012). Association of coffee drinking with total and cause-specific mortality. N. Engl. J. Med., 366(20), 1891-1904

Gant, A., Leyva, V. E., Gonzalez, A. E., \& Maruenda, H. (2015). Validated HPLC-Diode Array Detector for Simultaneous Evaluation of Six Quality Markers in Coffee. Journal of AOAC International, 98(1), 98-102(5). https://doi.org/10.5740/jaoacint.14-113

García-Moraleja, A., Font, G., Mañes, J., \& Ferrer, E. (2015). Simultaneous determination of mycotoxin in commercial coffee. Food control, 57, 282-292. https://doi.org/10.1016/j.foodcont.2015.04.031

Gennano, M. C., \& Abrigo, C. (1992). Caffeine and theobromine in coffee, tea and cola beverages simultaneous determination by reversed-phase ion interaction HPLC. Frenesius J. Anal. Chem., 343, 523-525. https://doi.org/10.1007/bf00322162

Gonzalez, A. G., Pablos, F., Martin, M. J., Leon-Camacho, M., \& Valdenebro, M. S. (2001). HPLC analysis of tocopherols and triglycerides in coffee and then use as authentication parameters. Food Chem., 73, 93-101. https://doi.org/10.1016/s0308-8146(00)00282-x 
Granvogl, M., \& Schieberle, P. (2007). Quantification of 3-aminopropionamide in cocoa, coffee and cereal products. Eur. Food Res. Technol., 225, 857-863. https://doi.org/10.1007/s00217-006-0492-9

Grollier, J. F., \& Plessis, S. (1998). Use of coffee bean oil as a sun filter. U.S. Patent 4793990.

Guatemala-Morales, G. M., Beltrán-Medina, E. A., Murillo-Tovar, M. A., Ruiz-Palomino, P., Corona-González, R. I., \& Arriola-Guevara, E. (2016). Validation of analytical conditions for determination of polycyclic aromatic hydrocarbons in roasted coffee by gas chromatography-mass spectrometry. Food Chemistry, 197, 747-753. https://doi.org/10.1016/j.foodchem.2015.10.135

Guerrero, G., Suarez, M., \& Moreno, G. (2001). Hydroxycinnamic acids as genotype discrimination criteria for green coffee beans. ASIC $19^{\text {th }}$ Colloquium, Trieste, Italy.

Harada, K., Nishimura, O., \& Mihara, S. (1987). Rapid analysis of coffee flavour by gas chromatography using a pyrolyzer. J. Chromatography, 391, 457-600.

Holscher, N., \& Steinhart, H. (1992). Investigation of roasted coffee freshness with on improved headspace technique. Z. Lebensm.-Unters. Forsch., 195, 33-38. https://doi.org/10.1007/bf01197836

Ioffe, B., \& Vitenberg, A. G. (1984). Headspace analysis and related methods in gas chromatography. A Willey-Interscience Publication. New York

Kayali-Sayadi, M. N., Rubio-Barroso, S., Cuesta-Jimenez, M. P., \& Polo-Diez, L. M. (1999). A new method for the determination of selected PAHs in coffee brew samples by HPLC with fluorimetric detection and solid-phase extraction. J. Liquid Chromatogr. And Related Techn., 22, 615-627.

Kele, M., \& Ohmacht, R. (1996). Determination of serotonin released from coffee wax by liquid chromatography. J. Chromatography, 730, 53-62. https://doi.org/10.1016/0021-9673(95)01186-2

Kemsley, E. K., Ruault, S., \& Wilson, R. H. (1995). Discrimination between coffea Arabica and canephora variant robusta beans using infrared spectroscopy. Food Chem., 54, 321-326.

Khan, M. R., Alothman, Z. A., Naushad, M., Alomary, A. K., Alfadul, S. M., Alsohaimi, I. H., \& Algamdi, M. S. (2017). Occurrence of acrylamide carcinogen in Arabic coffee Qahwa, coffee and tea from Saudi Arabian market. Nature. 1-7. http://dx/doi.org/10.1038/srep41995

Kim, H. G., Hwang, Y. P., \& Jeong, H. G. (2009). Kahweol blocks STAT3 phosphorylation and induces apoptosis in human lung adenocarcinoma A549 cells. Toxicol. Lett., 187, 28-34. https://doi.org/10.1016/s0278-6915(02)00029-7

Knopp, S., Bytof, G., \& Selmar, D. (2006). Influence of processing on the content of sugars in green Arabica coffee beans. Eur. Food Res. Technol., 223, 195-201. https://doi.org/10.1007/s00217-005-0172-1

Kölling-Speer, I., Strohschneider, S., \& Speer, K. (1999). Determination of free diterpenes in green and roasted coffees. J. High Resol. Chromatogr, 22, 43-46. https://doi.org/10.1002/(sici)1521-4168(19990101)22:1\%3C43::aid-jhrc43\%3E3.3.co;2-g

Köseoglu, Yilmaz, P., \& Kolak, U. (2017). SPE-HPLC determination of chlorogenic and phenolic acids in coffee. J Chromatogr Sci., 18, 1-7. http://dx/doi.org/10.1093/chromosci/bmx025

Kramer, D., Breitensteub, B., Kleinwächter, M., \& Selmar, D. (2010). Stress metabolism in green coffee beans (coffea Arabica L.): expression of dehydrins and accumulation of GABA during drying. Plant \& Cell Physiology, 5l(4), 546-553. http://dx/doi.org/10.1093/pcp/pcq019

Krivan, V., Barth, P., \& Morales, F. (1993). Multielement analysis of green coffee and its possible use for the determination of origin. Mikrochim. Acta., 110, 217-236. https://doi.org/10.1007/bf01245106

Kurzrock, T., \& Speer, K. (2001). Identification of kahweol fatty acids esters in Arabica coffee by means of LC/MS. J. Sep. Sci., 24, 843-848. https://doi.org/10.1002/1615-9314(20011101)24:10/11\%3C843::aid-jssc843\%3E3.0.co;2-9

Ky, C. L., Lonarn, J., Dussert, S., Guyot, B., Hamon, S., \& Noirot, M. (2001). Caffeine, trigonelline, chlorogenic acids and sucrose diversity in wild coffee arabica L., C. canephora P., accessions. Food Chem., 75, 223-230. https://doi.org/10.1016/s0308-8146(01)00204-7

Lee, K. J., \& Jeong, H. G. (2007). Protective effects of kahweol and cafestol against hydrogen peroxide-induced oxidative stress and DNA damage. Toxicol. Lett., 173, 80-87. https://doi.org/10.1016/j.toxlet.2007.06.008

Lee, K. J., Choi, J. H., \& Jeong, H. G. (2007). Hepatoprotective and antioxidant effects of the coffee diterpenes kahweol and cafestol on carbon tetrachloride induced liver damage in mice. Food Chem. Toxicol., 45, 
2118-2125.

Lercker, G., Frega, N., Bocci, F., \& Rodriguez-Estrada, M. T. (1995). High resolution gas chromatographic determination of diterpenic alcohols and sterols in coffee lipids. Chromatographia., 41, 29-33. https://doi.org/10.1007/bf02274191

Levi, C. P. (1975). Determination of ochratoxin A in coffee by thin-layer chromatography. J. Assoc. Anal. Chem., $58,258-262$.

Mabrok, A. F., \& Deatheroge, F. E. (1956). Organic acid in brewed coffee. New York.

Maeztu, L., Sanz, C., Andueza, S., Paz, De Peña, M. , Bello, J., \& Cid, C. (2001). Characterization of Espresso Coffee Aroman by Static Headspace GC-MS and Sensory Flavor Profile. J. Agric. Food Chem., 49(11), 5437-5444. https://doi.org/10.1021/jf0107959

Martin, M. J., Pablos, F., \& Gonzalez, A. G. (1998). Characterization of green coffee varieties according to their metal content. Anal. Chim. Acta., 358, 103-104. https://doi.org/10.1016/s0003-2670(97)00610-7

Martin, M. J., Pablos, F., \& Gonzalez, A. G. (1998). Discrimination between Arabica and robusta green coffee varieties according to their chemical composition. Talanta, 46, 1259-1264. https://doi.org/10.1016/s0039-9140(97)00409-8

Martin, M. J., Pablos, F., \& Gonzalez, A. G. (1999). Characterization of Arabica and robusta roasted coffee varieties and mixture resolution according to their metal content. Food Chem., 66, 565-570. https://doi.org/10.1016/s0308-8146(99)00092-8

Martin, M. J., Pablos, F., Gonzalez, A. G., Valdenebro, M. S., \& Leon-Camacho, M. (2001). Fatty acid profiles as discriminant parameters for coffee varieties differentiation. Talanta., 54, 291-297. https://doi.org/10.1016/s0039-9140(00)00647-0

Meger, A., Ngiruwonsanga, T., \& Henze, G. (1996). Determination of adenine, caffeine, theophylline and theobromine by HPLC with amperometric detection. Frenesius J. Anal. Bioanal. Chem., 356, 284-287. https://doi.org/10.1007/s0021663560284

Mehari, B., Redi-Abshiro, M., Chandravanshi, B. S., Atalbachew, M., Combrinck, S., \& McCrindle, R. (2015). Simultaneous determination of alkaloids in green coffee beans from Ethiopia: Chemometric evaluation of geographic al origin. Food anal. Methods. https://doi.org/10.1007/s12161-016-0340-2

Moreira, A. S. P., Nunes, F. M., Domingues, M. R., \& Coimbra, M. A. (2012). Coffee melanoidins: structures, mechamisms of formation and potential health impacts. Food Funct., 3, 903. https://doi.org/10.1039/c2fo30048f

Morton, I. D., \& Macleod, A. D. (1986). Food Flavours: Part B, The flavor of beverages-Part 2. ISSN 0167-4501, Elsevier.

Mullen, W., Nemzer, B., Ou, B., Stalmach, A., Hunter, J., Clifford, M. N., \& Combet, E. (2011). The Antioxidant and Chlorogenic Acid Profiles of Whole Coffee Fruits Are Influenced by the Extraction Procedures. Journal of Agricultural and Food Chemistry, 59, 3754-3762. https://doi.org/10.1021/jf200122m

Mullen, W., Nemzer, B., Stalmach, A., Ali, S., \& Combet, E. (2013). Polyphenolic and Hydroxycinnamate Contents of Whole Coffee Fruits from China, India and Mexico. Journal of Agricultural and Food Chemistry, 61, 5298-5309. https://doi.org/10.1021/jf4003126

Murata, M., Okada, H., \& Homma, S. H. (1995). Hydroxycinnamic Acid-Derivatives and P-Coumaroyl-(L)-Tryprophon a Novel Hydroxycinnamic Acid-Derivative, from Coffee Beans. Biosci. Biotechnol. Biochem, 59, 1887-1890. https://doi.org/10.1271/bbb.59.1887

Nakhmedov, F. G. (1984). Technology of Coffee Products. Moscow. Consumer Goods and Food Industry, 184.

Nascimento, E. A., Morais, S. A. L., Chang, R., Aquino, F. J. T., Alves, B. H. P., \& Afonso, R. J. C. F. (2015). Looking for Unknown Molecules in Arabica and Robusta Coffee Brews by High Performance Liquid Chromatography Coupled to High Resolution Mass Spectrometry and Differentiating Both Coffee Species by this Technique. International Journal of Applied Science and Technology, 5(1), 26-37.

O'Driscoll, D. J. (2014). Analysis of coffee bean extracts by use of ultra-performance liquid chromatography coupled to quadrupole time-of-flight mass spectrometry. MethodsX, 1, 264-268.

https://doi.org/10/1016/j.mex.2014.10.006

O’Keefe, J. H., Bhatti, S. K., Patil, H. R., DiNicolantonio, J. J., Lucan, S. C., Lavie, C. J. (2013) Effects of 
habitual coffee consumption on cardiometabolic disease, cardiovascular health, and all-cause mortality. $J$. Am Coll. Cardiol, 62(12), 1043-1051.

Ono, H., Chuda, Y., Ohnishi-Kameyama, M., Yoda, H. Ishizaka, M., Kobayashi, H., \& Yochida, M. (2003). Analysis of acrilamide by LC-MS/MS and GC-MS in processed Japanese foods. Food Additives and Contaminants, 20, 215-220.

Perez-Martinez, L., Sagrado, S., \& Medina-Hermandez, M. J. (1995). A rapid procedure for determination of a caffeine, theophylline and theobromine in urine by miscellar liquid chromatography and direct sample injection. Anal. Chim. Acta., 304, 195-201. https://doi.org/10.1016/0003-2670(94)00619-w

Pérez-Hernández, L. M., Chávez-Quiroz, K., Medina-Juárez, L. Á., \& Meza, N. G. (2012). Phenolic characterization, melanoidins, and antioxidant activity of some commercial coffees from coffea Arabica and coffea canephora. J. Mex. Chem. Soc., 56(4), 430-435

Pettitt, B. C. (1987). Identification of the diterpene esters in Arabica and canephora coffees. J. Agric. Food Chem., 35, 549-551. https://doi.org/10.1021/jf00076a027

Pissinatti, R., Nunes, C. M., de Souza, A. G., Junqueira, R. G., \& de Souza, S. V. C. (2015). Simultaneous analysis of 10 polycyclic aromatic hydrocarbons in roasted coffee by isotope dilution gas chromatography-mass spectrometry: Optimization, in-house method validation and application to an exploratory study. Food Control., 51, 140-148. https://doi.org/10.1016/j.foodcont.2014.11.003

Procida, G., de Palo, D., \& Bogoni, P. (1997). Analysis of the volatile constituents of coffee by headspace GC-MS. Riv. Ital. EPPOS Spec., 251-261.

Rajkovic, M. B., Vukovic, G., Peric, L, Demin, M., Lalicic, J., \& Kovacevic, D. (2004). Analyzing of coffee quality with different methods. J. Agricultural Science, 49, 87-96. https://doi.org/10.2298/jas0401087r

Roach, J. A., Andrzejewski, D., Gay, M. L., Nortrup, D., \& Musser, S. M. (2003). Rugged LC-MS/MS survey analysis for acrylamide in foods. J. Agric. And Food Chem., 51, 7547-7554. https://doi.org/10.1021/jf0346354

Rocha, S., Maeztu, L., Barros, A., Cid, C., \& Coimbra, M. A. (2004). Screening and distinction of coffee brews based on head space solid-phase microextraction/gas chromatography/principal component analysis. $J$. Sci. Food Agric., 84, 43-51. https://doi.org/10.1002/jsfa.1607

Rodrigues, C., Maguas, C., \& Prohaska, T. (2010). Strontium and oxygen isotope fingerprinting of green coffee beans and its potential to proof authenticity of coffee. Eur. Food Res. Technol.

Roos, B., Van Der, Weg, G., Urgert, R., Bovenkamp, P., Charrier, A., \& Katan, M. (1997). Levels of cafestol, kahweol and related diterpenoids in wild species of the coffee plant. J. Agric. Food Chem., 45, 3065-3069. https://doi.org/10.1021/jf9700900

Rubayiza, A. B., \& Meurens, M. (2005). Chemical discrimination of Arabica and robusta coffees by Fourier transform Raman spectroscopy. J. Agric. Food Chem., 53, 4654-4659.

Ruiz, del Castillo, M. L., Herraiz, M., \& Blanch, G. P. (1999). Rapid analysis of cholesterol - elevating compounds in coffee brews by off-line high-performance liquid chromatography/high resolution gas chromatography. J. Agric. Food Chem., 47, 1525-1529.

Ryan, D., Shellie, R., Tranchida, P., Casilli, A., Mondello, L., \& Marriott, P. (2004). Analysis of roasted coffee bean volatiles by using comprehensive two-limensional gas chromatography-time-of-flight mass spectrometry. J. Chromatogr, 1054, 57-65. https://doi.org/10.1016/s0021-9673(04)01408-6

Sanz, C., Ansorena, D., Bello, J., \& Cid, C. (2001) Optimizing headspace temperature and time sampling for Identification of Volatile Compounds in Ground Roasted Arabica Coffee. J. Agric. Food Chem., 49, 1364-1369. https://doi.org/10.1021/jf001100r

Savolainen, H. (1992). Tannin content of tea and coffee. J apple toxicol., 12(3), 191-2. https://doi.org/10.1002/jat.2550120307

Semmeirich, P., \& Grosh, W. (1995). Analysis of roasted coffee powders and brews by Gas Chromatography-olfactomertry of headspace samples. Food Sci. Technol., 28, 310-313. https://doi.org/10.1016/s0023-6438(95)94411-7

Senyuva, H. Z., \& Gökmen, V. (2005). Study of acrylamide in coffee using an improved LC-MS method: Investigation color changes and acrylamide formation in coffee during roasting. Food Additives and 
Contaminants, 22, 214-220. https://doi.org/10.1080/02652030500109834

Serra, F., Guillou, C. G., Reniero, F., Ballarin, L. Cantagallo, M. I., Wieser, M., IYer, S. S., Héberger, K., \& Vanhaecke, F. (2005). Determination of the geographical origin of green coffee by principal component analysis of carbon nitrogen and boron stable isotope ratios. Rapid Commun. Mass Spectrom, 19, 2111-2115.

Seto Y., Ohmori T., Kanamori-Kataoka M., Tsuge K., \& Ohsawa I. (2008). Artifactual production of cyanide from coffee and tea drinks in the presence of nitrite. Annales de Toxicologic Analytique, 20, 155-160.

Shan, Y., Jin, X., Cheng, Y., \& Yan, W. (2016). Simultaneous determination of chlorogenic acids in green coffee bean extracts with effective relative response factors. International Journal of Food Properties, http://www.tandfonline.com/doi/abs/10.1080/10942912.2016.1230746

Shi, Y., Wu, H., Wang, C., Guo, X., Du, J., \& Du, L. (2016). Determination of polycyclic aromatic hydrocarbons in coffee and tea samples by magnetic solid-phase extraction coupled with HPLC-FLD. Food Chemistry, 199, 75-80. https://doi.org/10.1016/j.foodchem.2015.11.137

Suchanek, M., Filipova, H., Volka, K., Delgadillo, I., \& Davies, A. N. (1996). Qualitative analysis of green coffee by infrared spectrometry. Fresenius J. Anal. Chem., 354, 327-332. https://doi.org/10.1007/s0021663540327

Surma, M., Sadowska-Rociek, A., Cieślik, E., \& Sznajder-Katarzyńska, K. (2017). Optimization of QuECHERS sample preparation method for acrylamide level determination in coffee and coffee substitutes. Microchemical Journal, 131, 98-102. https://doi.org/10.1016/j.microc.2016.11.021

Taeymans, D., Wood, J., Ashby, P., Blank, I., Studer, A., Stadler, R. H., Gondé, P., Van Eijck, P., Lalljie, S., Lingnert, H., Lindblom, M., Matissek, R., Müller, D., Tallmadge, D., O'Brien, J., Thompson, S., Silvani, D., \& Whitmore, T. (2004). A Review of acrylamide: An industry perspective on research, analysis, formation and control. Crit. Reviews in Food Science and Nutrition, 44, 323-347.

Tarcke, E., Rydberg, P., Karlsson, S., Eriksson, S., \& Törnqvist, M. (2002). Analysis of acrylamide, a carcinogen formed in heated foodstuffs. J. Agric. And Food Chem., 50, 4998-5006. https://doi.org/10.1021/jf020302f

Trugo, L. (1984). High Performance Liquid Chromatography in coffee analysis. Ph.D.Thesis. University of Reading, England.

Trugo, L., Macrae, R., \& Dick, J. (1984). Chlorogenic acid composition of instant coffee. Analyst, 109, 263-266. https://doi.org/10.1039/an9840900263

Trugo, L. C., De Maria, C. A. B., Moreira, F. R. A., \& Petracco, M. (1995). Simultaneous determination of total chlorogenic acid, triginelline and caffeine in green coffee by high-performance gel filtration chromatography. Food Chem., 52, 447-449. https://doi.org/10.1016/0308-8146(95)93298-6

Urgert, R., Van Der, Weg, G., Kosmeijer-Schuil, T., van de Bovenkamp, P., Hovenier, R., \& Katan, M. (1995). Levels of the cholesterol-elevating diterpenes cafestol and kahweol in various coffee brews. J. Agric. Food Chem., 43, 2167-2172. https://doi.org/10.1021/jf00056a039

Valdenbro, M. S., Leon-Camacho, M., Pablos, F., Gonzalez, A. G., \& Martin, M. J. (1999). Determination of the Arabica/robusta composition of roasted coffee according to their sterolic content. Analyst, 124, 999-1002. https://doi.org/10.1039/a902245g

Ventura, M., Vallejos, C.,.Anaya, I. A., Broto-Puig, F., Agut, M., \& Comellas, L. (2003). Analysis of ochratoxin $\mathrm{A}$ in Coffee by Solid-Phase Cleaning and narrow-bore liquid Chromatography-Fluorescence detector-Mass spectrometry. J. Agric. Food Chem., 51, 7564-7567. https://doi.org/10.1021/jf034856+

Vitenberg, A. G., \& Ioffe, B. V. (1982). Gas Extraction in Chromatographic Analysis. Leningrad, Chemistry, 240.

Vorgas, E. A., Dos, Santos, E. A., \& Pittet, A. (2005). Determination of ochratoxin A in Green Coffee by Immunoaffinity Column Cleaning and Liquid Chromatography: collaborative study. J. AOAC Intern, 88, 773-779.

Wanyika, H. N., Gotebe, E. G., Gitu, L. M., Ngumba, E. K., \& Maritim, C. W. (2010). Determination of caffeine content of tea and instant coffee brands found in the Kenyan market. African Journal of Food Science, 4, 353-358.

Weckerle, B., Richling, E., Heirinch, S., \& Schreier, P. (2002). Origin assessment of green coffee (coffea Arabica) by multi-element stable isotope analysis of caffeine. Anal. Bioanal. Chem., 374, 886-890.

https://doi.org/10.1007/s00216-002-1560-z 
Wieser, E. M., Iyer, S. S., Krouse, H. P., \& Cantagallo, M. I. (2001). Variations in the boron isotope composition of coffea Arabica beans. Appl. Geochem, 16, 317-322. https://doi.org/10.1016/s0883-2927(00)00031-7

Yang, N., Lui, C., Liu, X., Degn, T. K., Munchow, M., \& Fisk, I. (2016). Determination of volatile marker compounds of common coffee roast defects. Food Chemistry, 211, 206-214. https://doi.org/10.1016/j.foodchem.2016.04.124

Zyzak, D. V., Sonders, R. A., Stojanovich, M., Tallmadge, D. H., Eberhart, B. L., Ewald, D. K., Gruber, D. C., Morsch, T. R., Strothers, M. A., Rizzi, G. P., \& Villagran, M. D. (2003). Acrylamide formation in heated foods. J. Agric. And Food Chem., 51, 4782-4787. https://doi.org/10.1021/jf034180i

\section{Copyrights}

Copyright for this article is retained by the author(s), with first publication rights granted to the journal.

This is an open-access article distributed under the terms and conditions of the Creative Commons Attribution license (http://creativecommons.org/licenses/by/4.0/). 